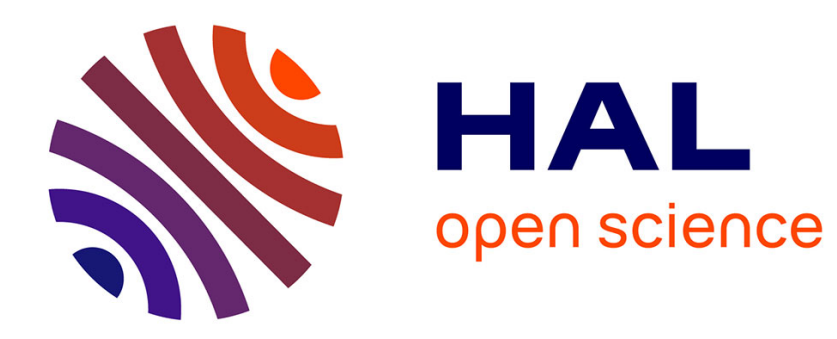

\title{
Trade integration and within-plant productivity evolution in Chile
}

\author{
Maria Bas, Ivan Ledezma
}

\section{To cite this version:}

Maria Bas, Ivan Ledezma. Trade integration and within-plant productivity evolution in Chile. Review of World Economics, 2010, 146 (1), pp.113-146. 10.1007/s10290-009-0041-2 . hal-00562714

\section{HAL Id: hal-00562714 https://hal.science/hal-00562714}

Submitted on 4 Feb 2011

HAL is a multi-disciplinary open access archive for the deposit and dissemination of scientific research documents, whether they are published or not. The documents may come from teaching and research institutions in France or abroad, or from public or private research centers.
L'archive ouverte pluridisciplinaire HAL, est destinée au dépôt et à la diffusion de documents scientifiques de niveau recherche, publiés ou non, émanant des établissements d'enseignement et de recherche français ou étrangers, des laboratoires publics ou privés. 


\title{
Trade integration and within-plant productivity evolution in Chile
}

\author{
Maria Bas • Ivan Ledezma
}

Published online: 4 February 2010

(C) Kiel Institute 2010

\begin{abstract}
We analyze the impact of trade integration on plant TFP using Chilean plant-level data (1982-1999) and 3-digit bilateral trade flows. Our contribution is to disentangle the impact of export and import barriers, estimated as border effects within a multilateral context. A fall in export barriers is positively correlated with plant productivity in traded sectors. The reduction of import barriers, however, can only be associated to productivity improvements in export-oriented sectors. In import-competing sectors a robust positive correlation shows up between plant productivity and protection. We then test several channels linking trade integration and firm productivity.
\end{abstract}

Keywords Trade barriers · Plant productivity · Firm heterogeneity ·

Plant-level data

JEL Classification $\mathrm{F} 1 \cdot \mathrm{F} 4 \cdot \mathrm{O} 1$

\section{Introduction}

Trade liberalization was at the core of reform packages carried out in many developing economies during the 1980s. In this paper we revisit the case of Chile, one of the earliest and most radical examples of trade liberalization. We aim at testing the link between trade integration and productivity in Chilean manufacturing

\footnotetext{
M. Bas $(\bowtie)$

Paris School of Economics and CEPII (Centre d'Etudes Prospectives et d'Informations Internationales), Paris, France

e-mail: maria.bas@cepii.fr

I. Ledezma

Paris School of Economics and Université Paris-Dauphine LEDa-DIAL, Paris, France e-mail: ivan.ledezma@dauphine.fr
} 
plants. At the micro level, the impact of trade reforms is generally studied from a unilateral perspective through direct measures of trade costs or through aggregate trade ratios that may neglect several features of trade integration. The novelty of this paper is to estimate trade barriers in a multilateral context to disentangle within a unique framework, the effect of export- and import-oriented policies on plant productivity.

By differentiating between export and import barriers we deal with the multiple channels linking trade integration and plant productivity. This task of identification is important since the underlying forces can go in opposite directions. The reduction of import barriers increases foreign competition, which is often viewed as a positive engine of productivity (Pavcnik 2002; Amiti and Konings 2007). It pushes the least productive firms to cease production and surviving ones to trim down their inefficiencies. However, the presence of increasing returns to scale and imperfect competition may modify the relationship between import competition and plant productivity (Devarajan and Rodrik 1989; Rodrik 1992). One consequence of scale economies is precisely that average cost falls as output increases. In this case, foreign competition reduces domestic sales restricting the possibility to exploit scale economies.

Import-oriented policies not only implies the exposition to foreign competition. They also determine the extent of foreign technology transmissions. In developing countries, the access to high-quality capital equipment and intermediate goods from developed countries enables firms to raise their productivity level. Using plant-level data, Schor (2004) for Brazil, and Amiti and Konings (2007) for Indonesia show that input tariff reductions boost productivity gains. Similarly, Kasahara and Rodriguez (2008) for Chile find that the use of imported intermediates foster plant productivity.

On the export side, trade integration allows firms to benefit from positive spillovers stemming from foreign markets. The literature suggests learning-byexporting as a plausible mechanism to explain a positive impact of trade liberalization on plant productivity. While the question is still empirically open, there is some evidence on ex post productivity gains arising from knowledge and expertise gained in the export process. ${ }^{1}$

These different mechanisms of trade liberalization call for further analysis on the multiple dimensions of trade. We carry out a three-step empirical strategy. Firstly, we obtain estimates of plant total factor productivity (TFP) by estimating the production function at 2-digit industry level while addressing simultaneity issues thanks to the Levinsohn and Petrin (2003) methodology. These estimates draw on plant-level data (1979-1999) from the annual industry survey ENIA (Encuesta Nacional Industrial Anual) of the Chilean manufacturing sector provided by the INE (Instituto Nacional de Estadisticas). Secondly, we use bilateral trade flows of Chile and its main trade partners at the industry level (2-digit) to capture export and import barriers. To do so we rely on the border effect gravity framework developed by Fontagné et al. (2005) and use the Trade and Production database provided by the CEPII (Centre d'Etudes Prospecives

\footnotetext{
${ }^{1}$ See Kraay (2002) on China, Alvarez and Lopez (2005) on Chile, De Loecker (2007) on Slovenia.
} 
et d'Information Internationales). This strategy enables us to obtain time-varying measures of trade integration at the industry level. Unlike Chilean tariff rates, these measures do present heterogeneity across industries. Finally, in the third step we estimate the impact of import and export barriers on plant productivity by combining the results of the first two steps. Here we regress plant productivity on border effect estimates.

The paper yields new findings on trade policy implications. Considering productivity gains relative to non traded sectors, our results suggest that: (1) a reduction in export barriers fosters plant productivity in both export-oriented and import-competing industries; and that (2) the impact of import barriers depends on trade orientation. In import-competing industries a decrease in import barriers has a negative effect on plant productivity. We show that this result is related to the presence of increasing returns to scale (IRS) in these industries. Foreign competition may have dampened domestic sales and, thereby, reduced the possibility to exploit scale economies. In the case of export-oriented industries, a fall in import barriers is associated to plant productivity improvements. This result is present in different static specifications. Nevertheless, in the dynamic specification, when we control for past productivity levels, the negative effect of foreign competition also shows up in export-oriented industries.

Besides the above-mentioned mechanism of scale economies, we test other channels linking trade integration and productivity. Results here reveal productivity improvements arising from the access to foreign capital equipment (in both exportoriented and import-competing industries). Moreover, searching for deeper insights on the impact of foreign competition, we find that it depends on the distance to the technology frontier and on whether this competition comes from low-wage or highwage countries.

We carried out several robustness checks. The list includes alternative measures of productivity, different specifications dealing with potential mark-ups bias and dynamic concerns of the persistence of plant productivity over time. We also run our three-steps estimation using more disaggregated regressions of production functions and border effects (at 3-digit instead of 2-digit) and considering an enlarged sample of trade partners. Furthermore, in the different empirical stages we deal with the potential risk of reversal causality between trade barriers and plant productivity. This is done by purging productivity effects in the gravity specification, by using a 4-year rolling horizon in step 2 and by treating trade barriers as endogenous in GMM estimations.

Our findings contribute with new evidence on trade liberalization and plant productivity in Chile. The identification setting has been chosen to allow for a close comparison with previous results obtained by Pavcnik (2002) and Bergoeing et al. (2006). ${ }^{2}$ Both studies acknowledge the presence of time-varying firm heterogeneity and deal with the effects of trade integration on productivity gains in a similar and comparable identification strategy. Using plant-level data, Pavcnik (2002) estimates the impact of trade on plant productivity in Chile during the

\footnotetext{
${ }^{2}$ Several works have investigated the relationship between Chilean market-oriented reforms and plant productivity. See also Liu and Tybout (1996), Bergoeing et al. (2002, 2004), Alvarez and Lopez (2005).
} 
period 1979-1986. By the means of a difference-in-difference framework, Pavcnik (2002) concludes that trade liberalization induces the growth of within-plant productivity in import-competing industries. Productivity improvements in exportoriented industries are observed only for initial years. ${ }^{3}$ Using our sample, we are able to reproduce these results. However, contrary to what the difference-indifference specification assumes, trade exposure in Chile does not increase continuously during Pavcnik's sample period. Indeed, in the context of the 1982 debt crisis, the government rose import tariffs from $15 \%$ in 1982 up to $35 \%$ in 1985.

Chilean trade reforms have been recently revisited by Bergoeing et al. (2006). They study the impact of the financial and trade reforms on productivity gains in Chile during a longer period (1980-2001). The authors show that if one uses effective tariffs instead of year dummies to capture trade liberalization, plant productivity advantages in export-oriented industries are not significant and, similar to our results, productivity gains of plants belonging to import-competing industries fall after trade liberalization.

Nevertheless, both studies suffer from the lack of cross-section variance on the right-hand side of regressions. Indeed, the identification of trade liberalization effects can be problematic since the reduction in import tariffs was homogeneous across industries and remained almost constant during the 1990s. The radical drop in the average nominal tariff rate from $98 \%$ in 1973 to $10 \%$ in 1979 came along with the homogenization of tariff rates among industries. Even their rise in early 1980s, during the debt crisis, was uniform. This homogeneous tariff reduction is probably the reason why Pavcnik (2002) is constrained to use time dummy indicators and Bergoeing et al. (2006) can not get enough variance for their estimates concerning export-oriented industries.

Considering direct measures of trade policy such as import tariffs also neglects two important features of trade integration. First, a unilateral import tariff reduction does not necessarily imply a symmetric response across trade partners. Second, several direct and indirect trade barriers might be omitted (Anderson and van Wincoop 2004). Among them, one finds not only non-tariff barriers (NTBs), but also bilateral agreements, institutional arrangements, infrastructure and even political efforts. The picture depicted by the evolution of tariffs in Chile does not completely reflect the different policy instruments applied by the government in order to promote exports and imports. For instance, during the eighties the government established an export promotion program and an economic positioning campaign to diffuse the country image in external markets. At the beginning of 1990s a Commercial Information System (CIS) was implemented to provide firms with information about international markets. During that decade, the new democracy set several free trade agreements (FTAs) with Latin American countries. This meant further reductions of import tariff and non-tariff barriers and the improvement of market access for Chilean exporters in manufacturing. Table 14 in

\footnotetext{
${ }^{3}$ Pavcnik (2002) also performs the Olley and Pakes (1996) aggregate productivity decomposition and shows that, in the period, aggregate productivity growth is mainly explained by the exit of the least productive firms and the reallocation of market shares towards most productive ones.
} 
Appendix 2 summarizes the key trade policy instruments implemented by Chile from 1975 to 2004 .

By estimating the evolution of trade integration between Chile and its trading partners, we are able to capture this type of missing information. This strategy also allows us to address the lack of cross-section variance of standard trade measures and to capture the multiple channels of trade integration. These are the main contributions relative to previous works.

The rest of the paper is structured as follows. Section 2 presents the estimation strategy of our empirical exercises. Section 3 shows the results and, finally, Sect. 4 presents a brief conclusion.

\section{Estimation strategy}

The estimation strategy consists of three steps. In the first one, we estimate the production function using ordinary least squares (OLS), fixed-effect (FE) specification and the Levinsohn and Petrin (2003) methodology to obtain plant TFP as a residual. In the second step, we construct the measure of trade liberalization by estimating border effects between partners following Fontagné et al. (2005). Finally, in the third step, we estimate the impact of trade barriers by regressing productivity on border effect estimates. Within this methodology, we address simultaneity issues in the estimation of TFP (step 1) and reversal causality between productivity and trade flows (step 2 and 3 ).

\subsection{Step 1: production function}

We estimate the following specification of a Cobb-Douglas production function at the 2-digit industry level:

$$
y_{p t}=\beta_{0}+\beta_{x} x_{p t}+\beta_{k} k_{p t}+\varepsilon_{p t}
$$

where all variables are expressed in natural logs, $y_{p t}$ is the value added of plant $p$ at time $t$, which is explained by short-term adjustable inputs $x_{p t}$ (i.e. skilled and unskilled labour) and capital stock $k_{p t}$. The error term can be decomposed into an intrinsical "transmitted" component $\omega_{p t}$ (productivity shock) and an i.i.d. component $\chi_{p t}$. Consequently, plant TFP $a_{p t}$ is calculated as the residual given by the difference between the observed output and the predicted factor contribution:

$$
\widehat{a}_{p t}=y_{p t}-\widehat{\beta}_{x} x_{p t}-\widehat{\beta}_{k} k_{p t}
$$

When estimating production functions using firm panel data, eventual problems concerning simultaneity and selection should be considered. Simultaneity arises because input demand and unobserved productivity are positively correlated. Firmspecific productivity is known by the firm but not by the econometrician. If a firm expects a high productivity shock it will anticipate an increase in its final good demand and, consequently, it will purchase more inputs. OLS will tend to provide upwardly biased estimates of the labour elasticity and downwardly biased estimates 
of the capital one. ${ }^{4}$ Selection problems are likely to be present because the unobserved productivity influences the exit decision of the firm and we can only observe those firms that stay in the market. On the other hand, if capital is positively correlated with profits, firms with larger capital stock will decide to stay in the market even for low realizations of productivity shocks. This implies a potential source of negative correlation in the sample between productivity shocks and capital stock, which translates into a downward bias in capital elasticity estimates.

Olley and Pakes (1996) (henceforth OP) propose a three-stage methodology to control for the unobserved firm productivity. They deal explicitly with exit and investment behaviour. The rationale is to reveal the unobserved productivity through the investment behaviour of the firm, which in turns depends, theoretically, on capital and productivity. Selection issues are taken into account by inferring that firms that stay in the market have decided to do it accordingly to their capital stock and their expectations of productivity. By the means of this theoretical exit rule, OP estimate survival probabilities conditional on firm's available information. These probabilities are then used in the productivity estimation.

Levinsohn and Petrin (2003; henceforth LP) extend the OP idea, by noting that some inputs, such as electricity or materials, can be better proxies than investment to control for the unobserved firm productivity when one deals with simultaneity. Inputs adjust in a more flexible way, so they are more responsive to productivity shocks. Moreover, inputs usually have more non-zero observations than investment, a property that has consequences on estimation efficiency. In the case of the ENIA survey this property is important. Thus, in order to maximize sample size we keep the LP strategy and use electricity as a proxy for unobserved productivity. ${ }^{5}$

There are some advantages of OP-LP methodologies. Firstly, they perform better than fixed-effect specifications because the unobserved individual effect (productivity) is not constrained to be constant over time. Secondly, approaches based on instrumental variables can be limited by the instruments availability. Finally, OP-LP do not assume restrictions on the parameters. For instance, an alternative approach is the one developed by Katayama et al. (2009) who show how misleading can be the use of sale revenues to measure productivity. Factor prices and mark-ups can produce important distortions if they are not homogeneous. However, their methodology assumes constant returns to scale and neglect entry-exit process to facilitate likelihood estimates. Again both assumptions are not neutral in the case of the ENIA. In the third step, we allow for plant's individual fixed effects and control for market concentration at a disaggregated industry level in order to reduce the potential risk of mark-up bias.

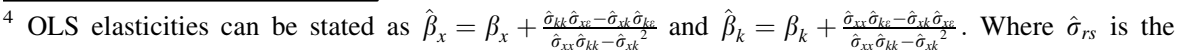
covariance between variables $r$ and $s$ in the sample. If capital is positively correlated with labour and labour's correlation with the productivity shock is higher than capital one (which is the realistic case) then the coefficient of capital $\hat{\beta}_{k}$ will be underestimated and the one of labour $\hat{\beta}_{x}$ upward biased.

${ }^{5}$ Besides technical concerns, a key difference between LP and OP is that the former does not directly take into account selection. However, as LP show, the risk of selection biases are significantly reduced by considering an unbalanced panel.
} 


\subsection{Step 2: border effects}

It is well-known that the reduction of tariffs in Chile was homogeneous across industries. As a consequence, tariff rates do not provide enough cross-section variance. On the other hand, tariffs are not the only measure that matters to capture trade costs. One should also consider bilateral agreements, asymmetries between export and import costs and indirect difficulties to trade. ${ }^{6}$ Considering all these features of trade, we do obtain heterogeneity in both industrial and time dimensions.

To do so, we apply a border effect methodology. This type of empirical strategy provides an assessment of the level of trade integration by estimating a gravity-like model that considers, as a very intuitive benchmark, the difficulties encountered by domestic producers in reaching domestic (intra-border) destinations. ${ }^{7}$

\subsubsection{The methodology}

The identification strategy of Fontagné et al. (2005) builds on Head and Mayer (2000) gravity model derivation. This strategy seems suitable to measure Chilean trade integration as it corrects for the lack of theoretical foundations of earlier works and keeps the idea of using intra-national trade as a benchmark of trade integration. Moreover, it allows for asymmetries in the identification of trade barriers among partners, one of the main focus of this paper. Fontagné et al.'s (2005) theoretical foundation builds on a static monopolistic competition setting with increasing returns to scale for one-sector economies. Consider an instantaneous constant elasticity of substitution (CES) utility function in which the representative consumer of country $i$ has specific preferences $a_{i j t}^{s}$ for each variety $h$ depending on the exporter country $j$ (for the sake of clarity in the exposition of our empirical implementation, we indicate explicitly both industry $s$ and time $t$ specificity):

$$
U_{i t}^{s}=\left[\sum_{j=1}^{N_{t}^{s}} \sum_{h=1}^{M_{j t}^{s}}\left(a_{i j t}^{s} c_{i j h t}^{s}\right)^{\frac{\sigma_{t}-1}{\sigma_{t}}}\right]^{\frac{\sigma_{t}}{\sigma_{t}-1}}
$$

Thus, varieties belonging to the same country share the same weight in the utility function. Imports $m_{i j t}^{s}\left(=c_{i j t}^{s} p_{i j t}^{s}\right)$ of country $i$ from country $j$ are valuated at the point of consumption $p_{i j t}^{s}=p_{j t}^{s} \tau_{i j t}^{s}$. This includes the producer price $p_{j t}^{s}$ augmented of all trade $\operatorname{cost} \tau_{i j t}^{s}$, modeled as iceberg costs. Total expenditure for the industry $Y_{i t}^{s}=$ $\sum_{j^{\prime}=1}^{N_{t}^{s}} m_{i j^{\prime} t}^{s}$ considers all imports, including intra-national ones $m_{i i t}^{s}$. For symmetric varieties, this utility function (3) with constant elasticity $\sigma_{t}$ leads to the well-known demands:

\footnotetext{
6 Theoretically, these indirect difficulties include a large list of country specificities, namely bias of consumption towards home goods and the like. As long as they can be interpreted, at least in part, as the outcome of history and political efforts, we consider them as a part of the measure of trade integration.

7 McCallum (1995) applies this methodology to study market access between Canada and the US. Despite the high expected trade integration, trade between US and Canada is found to be around 22 times more difficult than Canadian intra-national trade. Anderson and van Wincoop (2003) reestimate McCallum's (1995) model, correcting for multilateral price bias, and the assessment still remains striking.
} 


$$
m_{i j t}^{s}=\left(\frac{p_{j t}^{s} \tau_{i j t}^{s}}{a_{i j t}^{s} P_{i t}^{s}}\right)^{1-\sigma_{t}} M_{j t}^{s} Y_{i t}^{s}
$$

In this gravity-like Eq. $4, P_{i t}^{s}=\left[\sum_{j^{\prime}=1}^{N_{t}}\left(\frac{p_{i j^{\prime} t}}{a_{i j^{\prime} t}}\right)^{1-\sigma_{t}} M_{j^{\prime} t}^{s}\right]^{\frac{1}{1-\sigma_{t}}}$ is the consumer price of all varieties in the industry. This index takes into account differences in price setting across countries. If omitted, not only a multilateral control is missing but also a bias is induced between the error term and the partners dummies (border effect). Anderson and van Wincoop (2003) argue that the omission of multilateral price effects (what they call "multilateral resistances") explains the upward bias in border effects of Canada vis-à-vis the US estimated by McCallum (1995). ${ }^{8}$

One might mention four possible strategies to consistently estimate a gravity equation including price effects. The first one is to use price index data. Baier and Bergstrand (2001) follow this strategy measuring prices with GDP deflators. However, as highlighted by Anderson and van Wincoop (2004), empirical counterparts of $P_{i t}^{s}$ such as consumer price index (CPI) measures neglect changes in the true set of varieties and do not accurately reflect non-tariff barriers and indirect trade policies. The second strategy is the one followed by Anderson and van Wincoop (2003). They develop a two-step methodology in which border effect estimates are used to measure multilateral price effects. Besides practical difficulties of implementation, one crucial limitation for our purposes is the assumption of symmetry in bilateral trade costs. A third alternative approach uses fixed-effect specification to control for unobservable prices. The effect of price indexes is captured by the coefficients of individual fixed effects related to country source and destination (Harrigan 1996). Feenstra (2003) shows that the coefficients of fixedeffect estimation are consistent and reports values very similar to the non-linear least squares estimation of Anderson and van Wincoop (2003). Redding and Venables (2004) construct market access measures to explain cross-country differences in per capita income. Their market access estimation relies on fixed country effects to capture exporting and importing country characteristics. These country indicators take into account unobserved economic variables associated with supply and market capacity.

If the economic and geographic determinants captured by fixed effects vary over time, a useful strategy consists in eliminating the price index in the CES demand setting by expressing inter-national imports relative to intra-national ones. This is what Head and Mayer (2000) do. We follow this solution and divide Eq. 4 by $m_{i i t}^{s}$ :

$$
\frac{m_{i j t}^{s}}{m_{i i t}^{s}}=\left(\frac{a_{i j t}^{s}}{a_{i i t}^{s}}\right)^{\sigma_{t}-1}\left(\frac{p_{j t}^{s}}{p_{i t}^{s}}\right)^{-\sigma_{t}}\left(\frac{\tau_{i j t}^{s}}{\tau_{i i t}^{s}}\right)^{1-\sigma_{t}}\left(\frac{v_{j t}^{s}}{v_{i t}^{s}}\right)
$$

where $\frac{v_{j t}^{s}}{v_{i t}^{s}}$ is the relative value added between countries $i$ and $j$ for the industry $s$. It allows to capture the relative number of symmetric varieties within a model of monopolistic competition. To obtain an empirical counterpart of Eq. 5 we assume, as Fontagné et al. (2005), that trade costs $\left(\tau_{i j t}^{s}\right)$ are composed of transport cost

\footnotetext{
8 See previous footnote
} 
(captured by distance $d_{i j}$ ), ad valorem tariffs $\left(t_{i j t}^{s}\right)$ and the "tariff-equivalent" of nontariff barriers $\left(N T B_{i j t}^{s}\right)$. That is to say, $\tau_{i j t}^{s} \equiv\left(d_{i j}\right)^{\delta t}\left(1+t_{i j t}^{s}\right)\left(1+N T B_{i j t}^{s}\right)$.

Protection (tariffs and non-tariff barriers) varies across all partner pairs and depends on the direction of the flow for a given pair. To capture this, we define $\left(1+t_{i j t}^{s}\right)\left(1+N T B_{i j t}^{s}\right) \equiv \exp \left[\sum_{a} \sum_{b} \gamma_{a b t}^{s} B_{a b}\right]$, where $B_{a b}$ is a dummy that equals 1 if country $i$ belongs to region $a$ and country jto region $b$.

Preferences $a_{i j t}^{s}$ are supposed to have a random component $e_{i j t}^{s}$ and a systematic domestic bias $\beta_{i t}^{s}$ for goods produced in the home country $i$. This home market bias is reduced when countries $i$ and $j$ share the same language and are contiguous. The dummies $L_{i j}$ and $C_{i j}$ are defined to capture each situation, respectively. Under these assumptions preferences can be written as $a_{i j t}^{s} \equiv \exp \left[e_{i j t}^{s}-\left(\beta_{i t}^{s}-\lambda_{L t} L_{i j}-\right.\right.$ $\left.\left.\lambda_{C t} C_{i j}\right) \sum_{a} \sum_{b} B_{a b}\right]$, where $\lambda_{L t}$ and $\lambda_{C t}$ represent the extent to which the home market bias is mitigated by common language and contiguity. Taking into account all this dummy structure, Eq. 5, can be written as:

$$
\begin{aligned}
\ln \left(\frac{m_{i j t}^{s}}{m_{i i t}^{s}}\right)= & \ln \left(\frac{v_{j t}^{s}}{v_{i t}^{s}}\right)-\left(\sigma_{t}-1\right) \delta_{t} \ln \left(\frac{d_{i j}}{d_{i i}}\right)-\left(\sigma_{t}-1\right) \lambda_{L t} L_{i j}-\left(\sigma_{t}-1\right) \lambda_{C t} C_{i j} \\
& -\sigma_{t} \ln \left(\frac{p_{j t}^{s}}{p_{i t}^{s}}\right)-\sum_{a} \sum_{b}\left(\sigma_{t}-1\right)\left(\beta_{i t}^{s}+\gamma_{a b t}^{s}\right) B_{a b} \\
& +\left(\sigma_{t}-1\right)\left(e_{i j t}^{s}-e_{i i t}^{s}\right)
\end{aligned}
$$

\subsubsection{Empirical specification}

The number of observations in our bilateral flow sample does not allow to split the regressions by each year and 2-digit industry. In order to consistently estimate Eq. 6, we run pooled regressions in a 4-years rolling window for each industry. This allows us to obtain time-varying elasticities. Our estimable equation is now given by:

$$
\begin{aligned}
\ln \left(\frac{m_{i j t}^{s}}{m_{i i t}^{s}}\right)= & \alpha_{1 t^{\prime}} \ln \left(\frac{v_{j t}^{s}}{v_{i t}^{s}}\right)+\alpha_{2 t^{\prime}} \ln \left(\frac{d_{i j}}{d_{i i}}\right)+\alpha_{3 t^{\prime}} L_{i j}+\alpha_{4 t^{\prime}} C_{i j}+\alpha_{5 t^{\prime}} \ln \left(\frac{p_{j t}^{s}}{p_{i t}^{s}}\right) \\
& +\sum_{a} \sum_{b} \eta_{a b t^{\prime}}^{s} B_{a b}+\epsilon_{i j t}
\end{aligned}
$$

Where the theoretical counterpart of $\left\{\alpha_{1 t^{\prime}}, \alpha_{2 t^{\prime}}, \alpha_{3 t^{\prime}}, \alpha_{4 t^{\prime}}, \alpha_{5 t^{\prime}}, \eta_{a b t^{\prime}}^{s}\right\}$ is given by Eq. 6. We split the sample by each 2-digit industry and periods $t=t^{\prime}-3$ to $t^{\prime}$, where $t^{\prime}$ runs from 1982 to 1999 . Hence, $\eta_{a b t^{\prime}}^{s}$ will capture the average border effects of import of $a$ from $b$ (i.e. $\left.-\left(\sigma_{t}-1\right)\left(\beta_{i t}^{s}+\gamma_{a b t}^{s}\right)\right)$ for $t \in\left[t^{\prime}-3, t^{\prime}\right]$. Conversely, the border effect associated to export from $a$ to $b$ will be given by $\eta_{b a t^{\prime}}^{s}$. As Fontagné et al. (2005), we drop the constant and incorporate all dummy variables $B_{a b}$, whose estimated coefficients can be directly interpreted as border effects.

In our regressions we consider bilateral trade flows of the main trade partners of Chile. The list includes the United States (USA), 9 European countries $(E U)$ and 6 Latin American countries $(L A)$. Thus $a, b \in\{E U, L A, U S A, C H L\}$. Hence, we obtain the border effects for each combination of regions, including intra-regional trade in 
the case of the European Union and Latin American partners. For each time period $t^{\prime}$, industry $s$ and flow direction (export or import), our proxies of trade barriers are aggregated as the weighted average of all border effects estimates in which Chile is involved. Weights are given by the share of the export or import flow on total export or import of Chile at time $t^{\prime}$.

We run OLS regressions and, due to the form of the error term, use Hubert and White corrected standard errors clustered at the importer-industry-year level to control for the expected correlation. In Eq. 7 we do not impose $\alpha_{1 t^{\prime}}=1$, as the theoretical Eq. 6 suggests, and allow for its empirical estimation.

Note that a potential endogeneity problem exits in the estimation of Eq. 7. In a monopolistic competition framework, prices and output are determined simultaneously. Fontagné et al. (2005) use aggregate prices (instead of industry-level ones). The underlying assumption is that prices at the national level are less correlated with profit maximization at the firm level. In our estimation, we adopt a different approach and use relative wages at the industry level. This choice is motivated by the potential reverse causality in step 3. As previously mentioned, we will use the border effect estimates to test the impact of trade liberalization on plant productivity for different industries. Most productive industries (or those producing high quality goods) will tend to increase their trade flows and induce a downward bias in the border effect estimates (step 2). Our assumption is that relative wages capture potential asymmetries in technology or efficiency and thereby they help to remove productivity concerns from the border effect estimates. ${ }^{9}$ Moreover, due to the 4 -year rolling horizon the border effect estimates include past values of trade flows, which allows for a lagged effect of the change in trade barriers. This also contributes to reduce the risk of reversal causality in step 3. We go further in the series of robustness checks of step 3 and treat border effects as endogenous regressors in the context of generalized method of moments (GMM) and dynamic estimates.

\subsection{Step 3: the impact of trade policy on plant TFP}

In this final step, we use the previous estimates of trade barriers to measure the impact of trade liberalization on plant productivity across export-oriented and import-competing industries relative to non-traded ones. The following reduced equation is estimated, analogous to the difference-in-difference framework implemented by Pavcnik (2002):

$$
\widehat{a}_{p t}=\theta_{0}+\beta B_{s t}+\zeta T_{s^{\prime}}+\delta B_{s t} \cdot T_{s^{\prime}}+\varphi Z_{p t}+\xi_{p t}
$$

where $\theta_{0}$ is the constant and $\xi_{p t}$ the error term. $\widehat{a}_{p t}$ is the log of TFP of plant $p$ at time $t$ estimated by the LP strategy. $B_{s t}$ is a vector of trade barriers estimates (import and export border effects) for the 2-digit industry $(s)$ in which the plant operates. $T_{s^{\prime}}$ is a vector of trade orientation dummies indicating if the plant belongs to exportoriented or import-competing industries. Similar to Pavcnik (2002), we classify

\footnotetext{
${ }^{9}$ In non-reported regressions we have used relative aggregate prices and also the lag of relative aggregate prices and relative wages. The resulting border-effect estimates are very close to those used in what follows.
} 
industries by trade orientation $\left(s^{\prime}\right)$ at the 3-digit industry level (see Appendix 1). Plants are classified as export-oriented if they belong to a 3-digit industry which has more than $15 \%$ of exports over total production and as import-competing if the industry has more than $15 \%$ of imports over total production. The rest are considered as non-traded. ${ }^{10}$ Our classification concerns the initial period of 1980 1986. The initial sample classification also helps to avoid endogeneity problems arising from the classification. As Pavcnik (2002) notes, classification at 3- or 4digit does not change significantly. Neither does it when considering the pre-sample period.

$Z_{p t}$ is a vector of plant characteristics: industry affiliation at 2 -digit ${ }^{11}$, indicators of entry and exit and plant characteristics that may change over time, namely the use of imported inputs and credit constraints. Similar to Bergoeing et al. (2006), we identify plants that may face liquidity constraints using as a proxy a loan tax payment at the plant level. In Chile, financial credits are subject to this tax. Credit is a dummy variable equal to one if the plant reports having paid this tax in a given year. This information is used as a signal that the plant has not been financial constraint. We also introduce year indicators to control for other macroeconomic shocks. The excluded categories are non-traded industries, the year 1982 and the industry 38. As a robustness check we use alternative measures of plant productivity and also control for variable mark-ups.

We are mainly interested in the estimates of the vector coefficient $\delta$ of the interaction terms $\left(B_{s t} \cdot T_{s^{\prime}}\right)$. Negative and significant coefficients mean that a reduction of trade barriers has a positive effect on productivity in traded industries (export-oriented and import-competing) relative to non-traded ones. The full set of interaction terms enables us to measure separately the effect of import and export barriers, depending on trade orientation.

\subsection{Data}

In the first step, we use plant-level data from the ENIA survey, which is provided by the Chilean institute of statistics INE. This survey is a manufacturing census of Chilean plants with more than 10 employees. Our data covers the period 1979-1999 and contains information of added value, materials, labour, investment and exports (only available from 1990). ${ }^{12}$ We used different specific deflators at the 3-digit level (ISIC Rev-2) and year base 1992 for added value, exports, materials and investment. For the latter, specific deflators are considered for infrastructure, vehicles and machinery. Capital series were constructed using the methodology of Bergoeing

\footnotetext{
${ }^{10}$ There are only two industries (351 and 384) that matched up to both categories. Nevertheless, the industry 351 (384) presents an export-output ratio of 0.82 (0.21) and an import-output ratio of 1.32 (2.01). Therefore these industries were classified as import competing. Our results remain unchanged if we consider a fourth category of export-import competing for industries 351 and 384.

11 We introduce industry indicators to control for specific characteristics of industries. In order to avoid possible colinearity issues, following Pavcnik (2002), the industry affiliation dummies are defined at the 2-digit industry level, while trade orientation dummies are defined at the 3-digit industry level.

12 The ENIA survey has been used in previous studies such as Pavcnik (2002), Liu and Tybout (1996), Levinsohn and Petrin (2003) and Bergoeing et al. (2006) for different sample periods.
} 
et al. (2006). ${ }^{13}$ Table 7 in Appendix 2 shows a description of the variables and Table 8 in Appendix 2 reports general descriptive statistics of the plant-level sample.

In the second step we use data from the Trade and Production Database constructed by CEPII. This is an extension of the data collected by Nicita and Olarreaga (2001) at the World Bank. The CEPII has filled many missing values for production variables using UNIDO and OECD-STAN (for OECD members). It has also completed trade data with the international trade database BACI of CEPII. The final bilateral trade data covers the period 1976-1999 for 67 developing and developed countries. It provides information on value added, export and import trade flows, origin and destination countries, wages and labour at the 3-digit industry level (ISIC Rev-2).

Detailed intra-national trade flows for our sample of countries are not available. Intra-national trade is computed as output minus exports. This requires an appropriate measure of internal distance that should take into account economic activity to weight internal regions (Head and Mayer 2000). For distance variables, contiguity and common language, we also used the CEPII database of internal and external distances. The CEPII uses specific city-level data in order to compute a matrix of distance including the geographic population density for each country. Distance between two countries is measured based on bilateral distance between cities weighted by the share of the city in the overall country's population.

In the regressions we use bilateral trade data for the main trading partners of Chile: nine members of the European Union throughout the whole period 1979-1999 (Germany, France, the United Kingdom, Italy, Belgium, Luxembourg, Ireland, the Netherlands and Denmark), the United States and seven Latin-American countries (Argentina, Brazil, Bolivia, Chile, Mexico, Uruguay and Venezuela). In the robustness checks we use a significantly enlarged sample including 177 countries.

\section{Results}

\subsection{Results of step 1: plant TFP estimates}

In this step we estimate the Cobb-Douglas production function in Eq. 1 at the 2digit industry level using OLS, fixed effects and the LP methodology. Table 1 shows the results. As expected, LP estimates of unskilled labour elasticities are generally the lowest and those of capital elasticities the highest. This means that the bias induced by the larger responsiveness of unskilled labour relative to capital is addressed. Considering the production function estimates by LP, we can not reject at $5 \%$ the null hypothesis of constant returns to scale in the Wald test in five exportoriented industries [Food (31); Wood (33); Non-metallic minerals (36) and Basic metals (37)]. On the other hand, industries with increasing returns are mainly import-competing [Textile (32), Paper (34), Chemicals (35) and Machinery(38)]. Thus, in these industries market size can affect the cost structure of firms.

13 We thank the authors for providing us with their Stata routine for capital series. 
Table 1 Production function estimates

\begin{tabular}{|c|c|c|c|c|c|c|c|}
\hline Industry & Factors $^{\mathrm{a}}$ & OLS & SE & Fixed effects & SE & $\mathrm{LP}^{\mathrm{b}}$ & SE \\
\hline \multirow[t]{2}{*}{ Food and beverage (31) } & $\mathrm{U}$ & 0.815 & $(0.010)$ & 0.627 & $(0.012)$ & 0.570 & $(0.024)$ \\
\hline & $\mathrm{S}$ & 0.359 & $(0.009)$ & 0.159 & $(0.008)$ & 0.212 & $(0.015)$ \\
\hline Obs: 18559 & $\mathrm{~K}$ & 0.250 & $(0.005)$ & 0.083 & $(0.007)$ & 0.208 & $(0.046)$ \\
\hline \multirow[t]{2}{*}{ Textile (32) } & $\mathrm{U}$ & 0.833 & $(0.011)$ & 0.777 & $(0.014)$ & 0.710 & $(0.024)$ \\
\hline & $\mathrm{S}$ & 0.202 & $(0.010)$ & 0.165 & $(0.009)$ & 0.174 & $(0.018)$ \\
\hline Obs: 11063 & $\mathrm{~K}$ & 0.206 & $(0.005)$ & 0.102 & $(0.008)$ & 0.249 & $(0.034)$ \\
\hline \multirow[t]{2}{*}{ Wood (33) } & $\mathrm{U}$ & 0.865 & $(0.017)$ & 0.849 & $(0.021)$ & 0.681 & $(0.034)$ \\
\hline & $\mathrm{S}$ & 0.208 & $(0.015)$ & 0.095 & $(0.014)$ & 0.131 & $(0.021)$ \\
\hline Obs: 5711 & $\mathrm{~K}$ & 0.209 & $(0.009)$ & 0.104 & $(0.013)$ & 0.275 & $(0.040)$ \\
\hline \multirow[t]{2}{*}{ Paper (34) } & $\mathrm{U}$ & 0.763 & $(0.018)$ & 0.539 & $(0.024)$ & 0.692 & $(0.044)$ \\
\hline & $\mathrm{S}$ & 0.252 & $(0.014)$ & 0.175 & $(0.015)$ & 0.207 & $(0.025)$ \\
\hline Obs: 3175 & $\mathrm{~K}$ & 0.229 & $(0.010)$ & 0.182 & $(0.014)$ & 0.299 & $(0.055)$ \\
\hline \multirow[t]{2}{*}{ Chemicals (35) } & $\mathrm{U}$ & 0.604 & $(0.016)$ & 0.639 & $(0.017)$ & 0.528 & $(0.045)$ \\
\hline & $\mathrm{S}$ & 0.337 & $(0.015)$ & 0.168 & $(0.013)$ & 0.266 & $(0.028)$ \\
\hline Obs: 6588 & $\mathrm{~K}$ & 0.294 & $(0.008)$ & 0.149 & $(0.011)$ & 0.354 & $(0.057)$ \\
\hline \multirow[t]{2}{*}{ Non metalic products (36) } & $\mathrm{U}$ & 0.780 & $(0.028)$ & 0.797 & $(0.031)$ & 0.577 & $(0.074)$ \\
\hline & $\mathrm{S}$ & 0.241 & $(0.026)$ & 0.130 & $(0.025)$ & 0.103 & $(0.049)$ \\
\hline Obs: 2153 & $\mathrm{~K}$ & 0.244 & $(0.013)$ & 0.136 & $(0.018)$ & 0.281 & $(0.074)$ \\
\hline \multirow[t]{2}{*}{ Basic metals (37) } & $\mathrm{U}$ & 0.280 & $(0.070)$ & 0.346 & $(0.061)$ & 0.217 & $(0.104)$ \\
\hline & $\mathrm{S}$ & 0.485 & $(0.063)$ & 0.161 & $(0.045)$ & 0.263 & $(0.094)$ \\
\hline Obs: 640 & $\mathrm{~K}$ & 0.412 & $(0.042)$ & 0.059 & $(0.049)$ & 0.290 & $(0.189)$ \\
\hline \multirow[t]{2}{*}{ Machinery (38) } & $\mathrm{U}$ & 0.897 & $(0.012)$ & 0.766 & $(0.015)$ & 0.767 & $(0.033)$ \\
\hline & $\mathrm{S}$ & 0.242 & $(0.011)$ & 0.204 & $(0.011)$ & 0.178 & $(0.022)$ \\
\hline Obs: 8524 & $\mathrm{~K}$ & 0.164 & $(0.006)$ & 0.111 & $(0.010)$ & 0.236 & $(0.058)$ \\
\hline
\end{tabular}

Standard errors (SE) in parentheses

a $U$ unskilled labour (production workers), $S$ skilled labour (non-production workers), $K$ capital stock

b Levinsohn and Petrin (2003) methodology using electricity to control for the unobserved plant heterogeneity. 250 replications are used for bootstrap. The Wald test of constant returns to scale is rejected for Textile (32), Paper (34), Chemicals (35) and Machinery (38) industries

After estimating production function elasticities, we calculate plant TFP as a residual. Figure 1 presents the average evolution of different measures of plant productivity: fixed effects (tfp_fe), LP (tfp_lp), OLS (tfp_ols) and labour productivity (In productivity).

As a first robustness check of our productivity measures, the figure shows that labour productivity and all TFP measures depict similar evolutions. Although FE and LP elasticities exhibit some differences, the TFP path illustrated by both measures is very similar. ${ }^{14}$

\footnotetext{
${ }^{14}$ Thus, even if the assumption of fixed effects may overestimate the capital elasticity and underestimate labour one, after computing all factors contribution, the evolution of the residual is not drastically affected.
} 


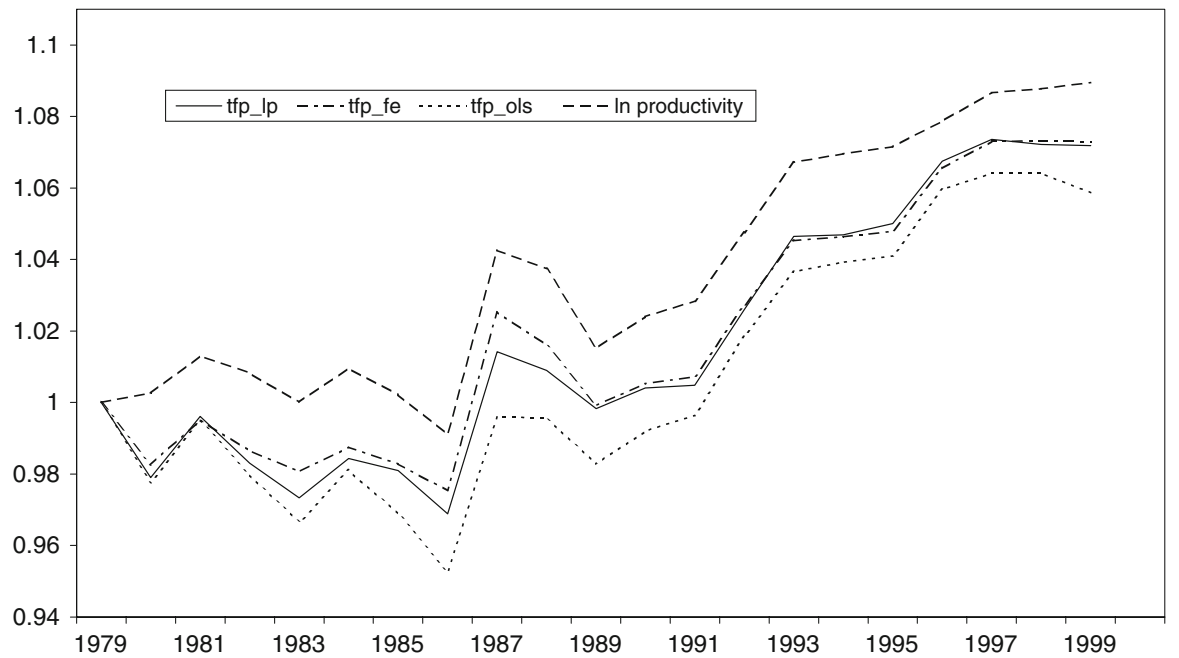

Fig. 1 Evolution of TFP estimates

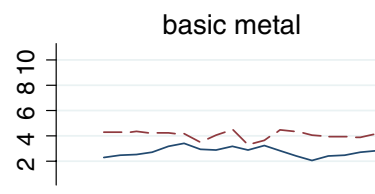

non metalic

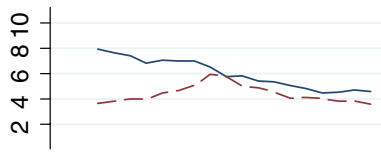

textil

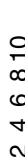

0
$\infty$
0
+
$\sim$

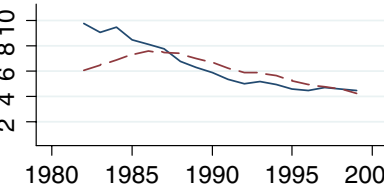

food

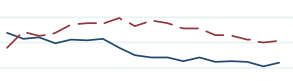

paper

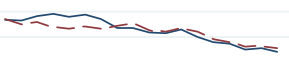

$\begin{array}{lllll}1980 & 1985 & 1990 & 1995 & 2000\end{array}$

machinery

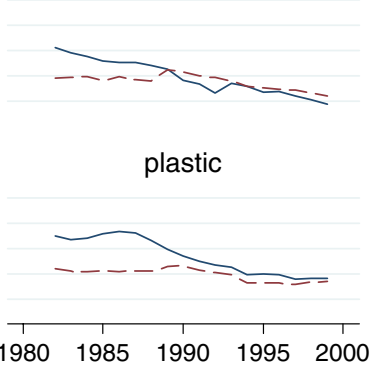

wood

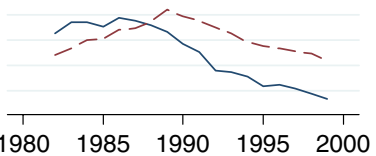

Year

\section{- border_effect_export ---- border_effect_import}

Fig. 2 Border effect estimates

\subsection{Results of step 2: border effect estimates}

In the second step, we construct market access measures by estimating Eq. 7 at the 2-digit industry level. This estimation captures the heterogeneity of trade barriers across industries. Figure 2 plots the weighted average of export and import border 
effect estimates across trade partners. Weights are based on each country export (import) share over total exports (imports) of Chile. All coefficients are significant at least at 5\%. The solid line depicts export border effects and the dashed line those corresponding to import.

Difficulties of Chilean exporters to access foreign markets (export border effect) were relatively constant at the beginning of the eighties. Reflecting the active trade agreement agenda, most industries switch to a downward trend at the end of the 1980s. This becomes specially pronounced during the 1990s. This is the case of Wood, Textiles, Plastics and Machinery. Two important export-oriented industries, Basic metals and Food, show an evolution of export border effect almost flat. The former, however, is the most traditional export-oriented industry and in this industry trade barriers were already low at the beginning of the period. On the other hand, the rather flat evolution of export barriers on Food industry might be explained by quality controls set by EU and the US. Home biases are also likely to be present in this type of industry. Once again one observes the extent to which direct trade measures such as import tariffs do not capture all dimensions of trade integration: export barriers have considerably diminished in all industries during the 1990s, even if import tariffs were already low.

Figure 2 also shows the evolution of the weighted measure of industry-level barriers faced by EU, LA and the US to access the Chilean market (import border effect). In many industries, import barriers increased during the first half of the 1980s (Food, Textiles, Wood, Non-metallics and Machinery). This is consistent with the raise in import tariffs during this period and also with other discretionary policy measures set to control the current account deficit during the debt crisis. Since we use a moving average of border effects, this tendency is observed even in the late 1980s as a lagged effect of protection. During the 1990s import border effects fall in almost all industries except in Basic metals. This reduction and convergence of import border effects seem also consistent with the new trade integration agenda of Chile based on bilateral and multilateral trade agreements.

\subsection{Results of step 3: the impact of trade barriers on plant TFP}

The final step consists in identifying the influence of each type of trade barrier on the evolution of plant productivity. Equation 8 disentangles the variation in productivity due to changes in trade barriers depending on trade orientation. We are interested in the vector coefficient $\delta$ of the interaction terms between trade orientation indicators and our border effect estimates.

\subsubsection{Reproducing Pavcnik's (2002) results}

In order to provide a baseline estimation, we start by reproducing Pavcnik's (2002) regressions for our full sample period. We use within group estimates in a difference-in-difference framework. In this specification, year indicators capture trade liberalization effects. These estimates are illustrated in Fig. 3. We obtain similar results to Pavcnik (2002). Once controlling for exit and plant-specific characteristics, trade liberalization (captured by time dummies) has a positive 


\section{Estimates of the Interaction of Import-Competing \\ Sector and Year Dummies}

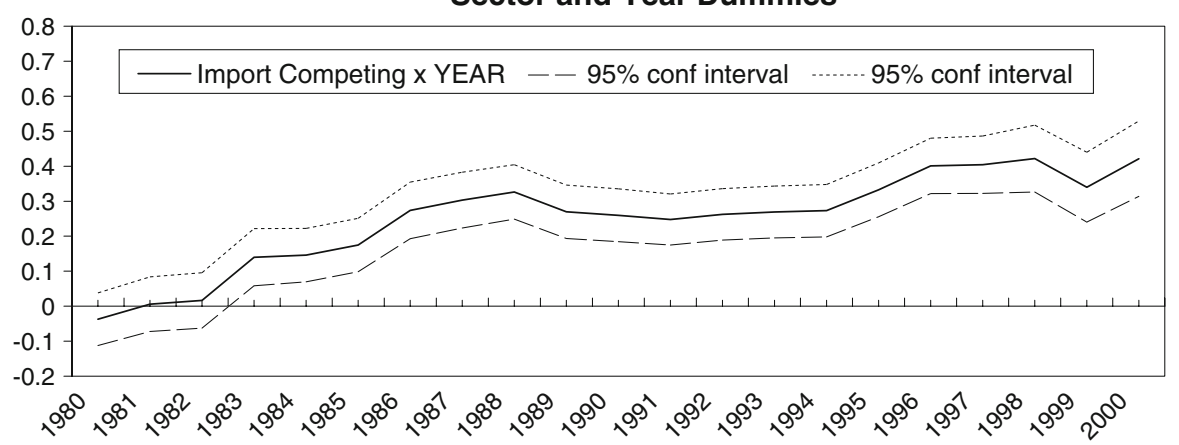

Estimates of the Interaction of Export-Oriented Sector and Year Dummies

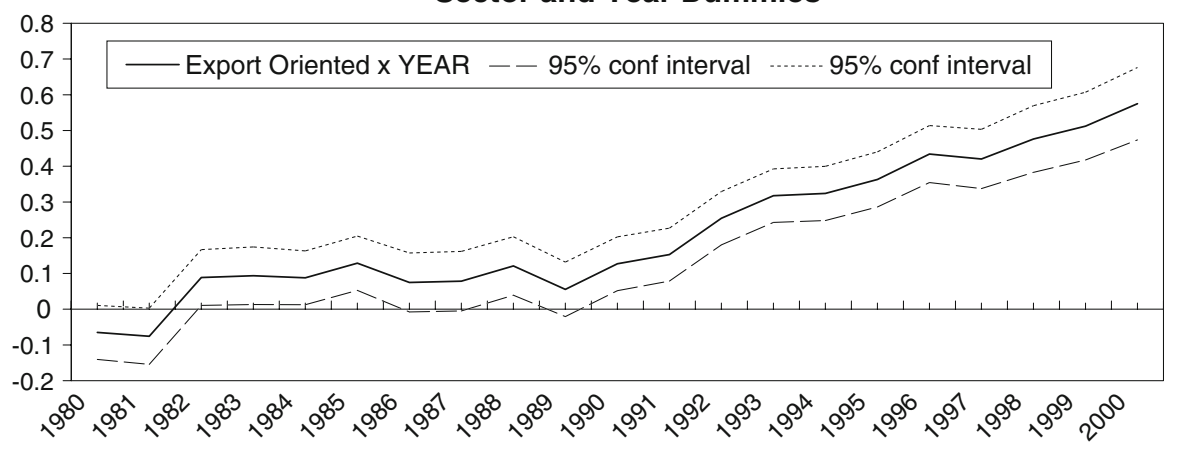

Fig. 3 Reproducing Pavcnik's (2002) results

impact on plant productivity in traded industries (export-oriented and importcompeting) relative to non-traded ones. Considering only the period 1980-1986, Pavcnik (2002) also highlights that plant productivity gains in export-oriented industries are minor. Using the full sample period, this trend changes after the 1990s.

\subsubsection{Disentangling the effects of export and import barriers}

In this section, we employ the weighted average border effects estimated in step 2. As previously mentioned, we use a 4-year rolling window for each industry. Hence, the border effect measures capture not only the current but also the lagged effect of trade integration on plant TFP. This implies the loss of initial years in the sample (1979-1981). On the other hand, these lagged measures of border effects and the controls introduced in step 2 to address asymmetric technologies reduce the risk of potential endogeneity between our measure of trade barriers and productivity. Additionally, in robustness check of dynamic specification we treat border effects as endogenous regressors in GMM estimations. 
Table 2 reports the results using the plant TFP measured by the LP methodology (TFP_LP). After controlling for industry-specific effects (2-digit industry indicators) and macroeconomic shocks (year indicators), the coefficients of the other variables should only capture the effects of within-industry productivity variation. We consider plant-fixed effects and use Huber-White standard errors in all estimations. In the last column, these errors are corrected for clustering at the plant level.

The first column presents the baseline estimation. In this specification we include the indicators for export-oriented (Export) and import-competing (Import) industries, the measures of import border effects $(\mathrm{BM})$ and export border effects $(\mathrm{BX})$ and their interactions (Export $\times$ BX, Import $\times$ BX, Export $\times$ BM, Import $\times$ BM). In this difference-in-difference framework we interpret the coefficients of interaction

Table 2 The impact of trade barriers on plant TFP (LP measure)

\begin{tabular}{|c|c|c|c|c|c|c|}
\hline & 1 & 2 & 3 & 4 & 5 & $6^{\mathrm{a}}$ \\
\hline Export & $\begin{array}{l}0.636 \\
\quad(0.078)^{* * * *}\end{array}$ & $\begin{array}{l}0.633 \\
\quad(0.078)^{* * * *}\end{array}$ & $\begin{array}{l}0.633 \\
\quad(0.078)^{* * *}\end{array}$ & $\begin{array}{l}0.638 \\
\quad(0.078)^{* * * *}\end{array}$ & $\begin{array}{l}0.635 \\
\quad(0.078)^{* * * *}\end{array}$ & $\begin{array}{l}0.635 \\
\quad(0.111)^{* * * *}\end{array}$ \\
\hline Import & $\begin{array}{l}0.283 \\
\quad(0.065)^{* * *}\end{array}$ & $\begin{array}{l}0.290 \\
\quad(0.065)^{* * * *}\end{array}$ & $\begin{array}{l}0.291 \\
\quad(0.065)^{* * *} *\end{array}$ & $\begin{array}{l}0.288 \\
\quad(0.065)^{* * * *}\end{array}$ & $\begin{array}{l}0.291 \\
\quad(0.065)^{* * *}\end{array}$ & $\begin{array}{l}0.291 \\
\quad(0.090)^{* * * *}\end{array}$ \\
\hline Export $\times \mathrm{BX}$ & $\begin{array}{l}-0.023 \\
\quad(0.007)^{* * *}\end{array}$ & $\begin{array}{l}-0.024 \\
\quad(0.007)^{* * * *}\end{array}$ & $\begin{array}{l}-0.023 \\
\quad(0.007)^{* * *}\end{array}$ & $\begin{array}{l}-0.025 \\
\quad(0.007)^{* * *}\end{array}$ & $\begin{array}{l}-0.025 \\
\quad(0.007)^{* * *}\end{array}$ & $\begin{array}{l}-0.025 \\
\quad(0.011)^{* *}\end{array}$ \\
\hline Import $\times \mathrm{BX}$ & $\begin{array}{l}-0.063 \\
\quad(0.007)^{* * * *}\end{array}$ & $\begin{array}{l}-0.062 \\
\quad(0.007)^{* * * *}\end{array}$ & $\begin{array}{l}-0.062 \\
\quad(0.007)^{* * *}\end{array}$ & $\begin{array}{l}-0.062 \\
\quad(0.007)^{* * * *}\end{array}$ & $\begin{array}{l}-0.062 \\
\quad(0.007)^{* * *}\end{array}$ & $\begin{array}{l}-0.062 \\
\quad(0.010)^{* * * *}\end{array}$ \\
\hline Export $\times \mathrm{BM}$ & $\begin{array}{l}-0.103 \\
\quad(0.011)^{* * *}\end{array}$ & $\begin{array}{l}-0.101 \\
\quad(0.011)^{* * *}\end{array}$ & $\begin{array}{l}-0.101 \\
\quad(0.011)^{* * *}\end{array}$ & $\begin{array}{l}-0.101 \\
\quad(0.011)^{* * *}\end{array}$ & $\begin{array}{l}-0.100 \\
\quad(0.011)^{* * *}\end{array}$ & $\begin{array}{l}-0.100 \\
\quad(0.015)^{* * *}\end{array}$ \\
\hline Import $\times \mathrm{BM}$ & $\begin{array}{l}0.040 \\
\quad(0.012)^{* * *}\end{array}$ & $\begin{array}{l}0.038 \\
\quad(0.012)^{* * * *}\end{array}$ & $\begin{array}{l}0.038 \\
\quad(0.012)^{* * * *}\end{array}$ & $\begin{array}{l}0.039 \\
\quad(0.012)^{* * *}\end{array}$ & $\begin{array}{l}0.039 \\
\quad(0.012)^{* * *}\end{array}$ & $\begin{array}{l}0.039 \\
\quad(0.016)^{* * *}\end{array}$ \\
\hline $\mathrm{BX}$ & $\begin{array}{l}0.095 \\
\quad(0.007)^{* * * *}\end{array}$ & $\begin{array}{l}0.095 \\
\quad(0.007)^{* * * *}\end{array}$ & $\begin{array}{l}0.095 \\
\quad(0.007)^{* * * *}\end{array}$ & $\begin{array}{l}0.095 \\
\quad(0.007)^{* * * *}\end{array}$ & $\begin{array}{l}0.095 \\
\quad(0.007)^{* * * *}\end{array}$ & $\begin{array}{l}0.095 \\
\quad(0.011)^{* * * *}\end{array}$ \\
\hline $\mathrm{BM}$ & $\begin{array}{l}0.083 \\
\quad(0.011)^{* * *}\end{array}$ & $\begin{array}{l}0.083 \\
\quad(0.011)^{* * * *}\end{array}$ & $\begin{array}{l}0.083 \\
\quad(0.011)^{* * * *}\end{array}$ & $\begin{array}{l}0.081 \\
\quad(0.011)^{* * * *}\end{array}$ & $\begin{array}{l}0.081 \\
\quad(0.011)^{* * * *}\end{array}$ & $\begin{array}{l}0.081 \\
\quad(0.014)^{* * * *}\end{array}$ \\
\hline Exit indicator & & $\begin{array}{l}-0.134 \\
\quad(0.013)^{* * * *}\end{array}$ & $\begin{array}{l}-0.139 \\
\quad(0.013)^{* * *} *\end{array}$ & $\begin{array}{l}-0.137 \\
\quad(0.013)^{* * *}\end{array}$ & $\begin{array}{l}-0.137 \\
\quad(0.013)^{* * *}\end{array}$ & $\begin{array}{l}-0.137 \\
\quad(0.013) * * *\end{array}$ \\
\hline Entry indicator & & & $\begin{array}{l}-0.063 \\
\quad(0.016)^{* * *}\end{array}$ & $\begin{array}{l}-0.063 \\
\quad(0.016)^{* * *}\end{array}$ & $\begin{array}{l}-0.063 \\
\quad(0.016)^{* * *}\end{array}$ & $\begin{array}{l}-0.063 \\
\quad(0.016)^{* * *}\end{array}$ \\
\hline Imported inputs & & & & $\begin{array}{l}0.051 \\
\quad(0.010)^{* * *}\end{array}$ & $\begin{array}{l}0.050 \\
\quad(0.010)^{* * *}\end{array}$ & $\begin{array}{l}0.050 \\
\quad(0.012)^{* * * *}\end{array}$ \\
\hline Credit & & & & & $\begin{array}{l}0.024 \\
\quad(0.009)^{* * * *}\end{array}$ & $\begin{array}{l}0.024 \\
\quad(0.011)^{* *}\end{array}$ \\
\hline Constant & $\begin{array}{l}5.284 \\
\quad(0.107)^{* * *}\end{array}$ & $\begin{array}{l}5.275 \\
\quad(0.108)^{* * * *}\end{array}$ & $\begin{array}{l}5.280 \\
\quad(0.107)^{* * * *}\end{array}$ & $\begin{array}{l}5.259 \\
\quad(0.107)^{* * * *}\end{array}$ & $\begin{array}{l}5.249 \\
\quad(0.107)^{* * * *}\end{array}$ & $\begin{array}{l}5.249 \\
\quad(0.136) * * *\end{array}$ \\
\hline $\begin{array}{l}\text { Plant, ISIC } 2 \text { and } \\
\text { year ind }\end{array}$ & Yes & Yes & Yes & Yes & Yes & Yes \\
\hline Number of obs & 46894 & 46894 & 46894 & 46894 & 46894 & 46894 \\
\hline Adjusted $R^{2}$ & 0.220 & 0.228 & 0.229 & 0.238 & 0.241 & 0.241 \\
\hline
\end{tabular}

Huber-White standard errors in parentheses

a Standard errors corrected for clustering at the plant level

$*$, **, *** denote significance at the level of 1,5 , and $10 \%$, respectively 
terms relative to non-traded industries (the omitted category). Export border effects interacted with both export-oriented (Export $\times$ BX) and import-competing $($ Import $\times \mathrm{BX})$ indicators present a negative and significant coefficient. This suggest a positive and significant impact of export barrier reductions on plant productivity in both traded industries. This result can be related to learning-byexporting and international knowledge spillovers (Kraay (2002) on China, Alvarez and Lopez (2005) on Chile and De Loecker (2007) on Slovenia). In the case of plants belonging to import-competing industries, the positive effect of export barrier reductions on their productivity could be driven by new-exporters within these industries. Bergoeing et al. (2005) show that, even if with a small aggregate export share, a number of plants entered the export market during the nineties in those Chilean industries.

The impact of import barriers depends on trade orientation. We find evidence of a negative effect of import barrier reductions on productivity of plants belonging to import-competing industries (Import $\times$ BM). Therefore, contrary to Pavcnik's (2002) results, in our regressions foreign competition appears to dampen plant productivity in those industries. The production function estimates (step 1) show that import-competing industries (Textile, Paper, Chemicals and Machinery) operate under increasing returns to scale (IRS). In this case, import competition reduces market shares of domestic firms shrinking the opportunities to exploit scale economies. This possible explanation has also been emphasized by Bergoeing et al. (2006) for different production function estimates and data treatment.

On the other hand, the reduction of import barriers has a positive impact on plant productivity in export-oriented industries (Export $\times$ BM). While import competition does not affect export sales, exporters also sell in the domestic markets and have to face foreign competitors. Hence, this category of exporters may help to isolate the "trimming fat" effect of foreign competition, since economies of scale are guaranteed for these firms by the access to international markets. The positive effect of the reduction of import barriers on plant productivity in export-oriented industries, in these static regressions, might come from innovative strategies implemented to improve domestic competitiveness. However, if one might expect a positive and a negative effect of foreign competition, for plants belonging to importcompeting industries the effect of market size reduction is negative enough to offset a positive outcome of import barrier reductions.

The above results (interaction terms) remain almost unchanged after the progressive inclusion of several controls. ${ }^{15}$ As expected, the exit indicator (Exit ind) has a negative coefficient (column 2). Exiting plants are on average 14\% less productive than surviving plants. The entry indicator (Entry ind) coefficient is also negative showing that new-entrants are roughly $6 \%$ less productive than incumbents (column 3). The use of imported inputs (Imported input) also appears to be positively correlated with productivity (column 4). The last column introduces a financial indicator (Credit). Although the coefficient is small, it has the expected

\footnotetext{
15 It is well documented in plant-level studies that multinationals are relatively productive, technologyintensive, and trade-intensive. Unfortunately, in our database, plant foreign status is only available since 1993.
} 
positive sign (column 5). Column 6 reports the results correcting for clustering at the plant level. Our estimates are still significant if one controls for intra group correlation.

\subsubsection{Robustness checks}

Alternative measures of productivity gains The previous results remain robust using alternative measures of plant productivity. First, we use the estimates of the production function using an individual fixed-effect specification (within-group estimates) instead of LP strategy to obtain the plant TFP in step 1. The first two columns of Table 3 report the results using this alternative measure of TFP (TFP_FE). Columns 3 and 4 show the results using labour productivity (Labour pr), measured as (deflated) value added per worker, and controlling for capital intensity (deflated capital stock over total labour). In both cases, the sign and the magnitude of the coefficients of the interaction terms between trade barriers and trade orientation indicators are very similar to those obtained in the previous specification (Table 2). Export barrier reductions improve plant productivity of firms in exportoriented and import-competing industries, while the fall in import barriers has only a positive impact on export-oriented industries and a negative effect on importcompeting ones. These findings confirm the previous results using plant TFP estimated by the LP strategy.

Enlarged country sample and 3-digit industry level intermediate estimates So far, we have estimated border effects at the 2-digit industry level and for the most representative trade partners of Chile for the manufacturing sector: the US, Latin America and Europe. ${ }^{16}$ As a robustness check, we compute border effects by estimating Eq. 7 at 3-digit (instead of 2-digit) over a significantly enlarged sample, including almost all countries of in the available information (177 countries). ${ }^{17} \mathrm{We}$ follow Santos Silva and Tenreyro (2006) and estimate the gravity model in its multiplicative form. The aim is to take into account the risk of bias due to heteroskedasticity and zero flows, which is significantly more prominent in this new sample. We use Zero Inflated Poisson (ZIP) to allow for a particular regime asociated to zero flows (see Greene 2008). Table 9 in Appendix 2 depicts the correlation between the previous estimates of border effects at 2-digit industry level and the ones estimated at 3-digit.

We also estimate the production function at 3-digit industry level in order to allow for further industry heterogeneity in technologies. Table 10 in Appendix 2 shows the average TFP of each desegregated industry at 3-digit. We then carry out the same baseline regressions using these more disaggregated estimates of border

\footnotetext{
${ }^{16}$ Exports to these countries represent $85 \%$ of total Chilean exports, while Chilean manufactured imports from these countries represent almost $80 \%$ of total imports in the nineties (ECLAC). During the nineties, manufactured exports to Asia represent only $3 \%$ of total Chilean exports, while imports from this continent represent $7 \%$.

17 We include all countries from the "Trade and Production" database except by African countries. The average trade flow between Africa and Chile is seven times lower than the average trade flow between Chile and the rest of the world. Even in the 75 percentile trade flow between Africa and Chile we find zero trade flows.
} 


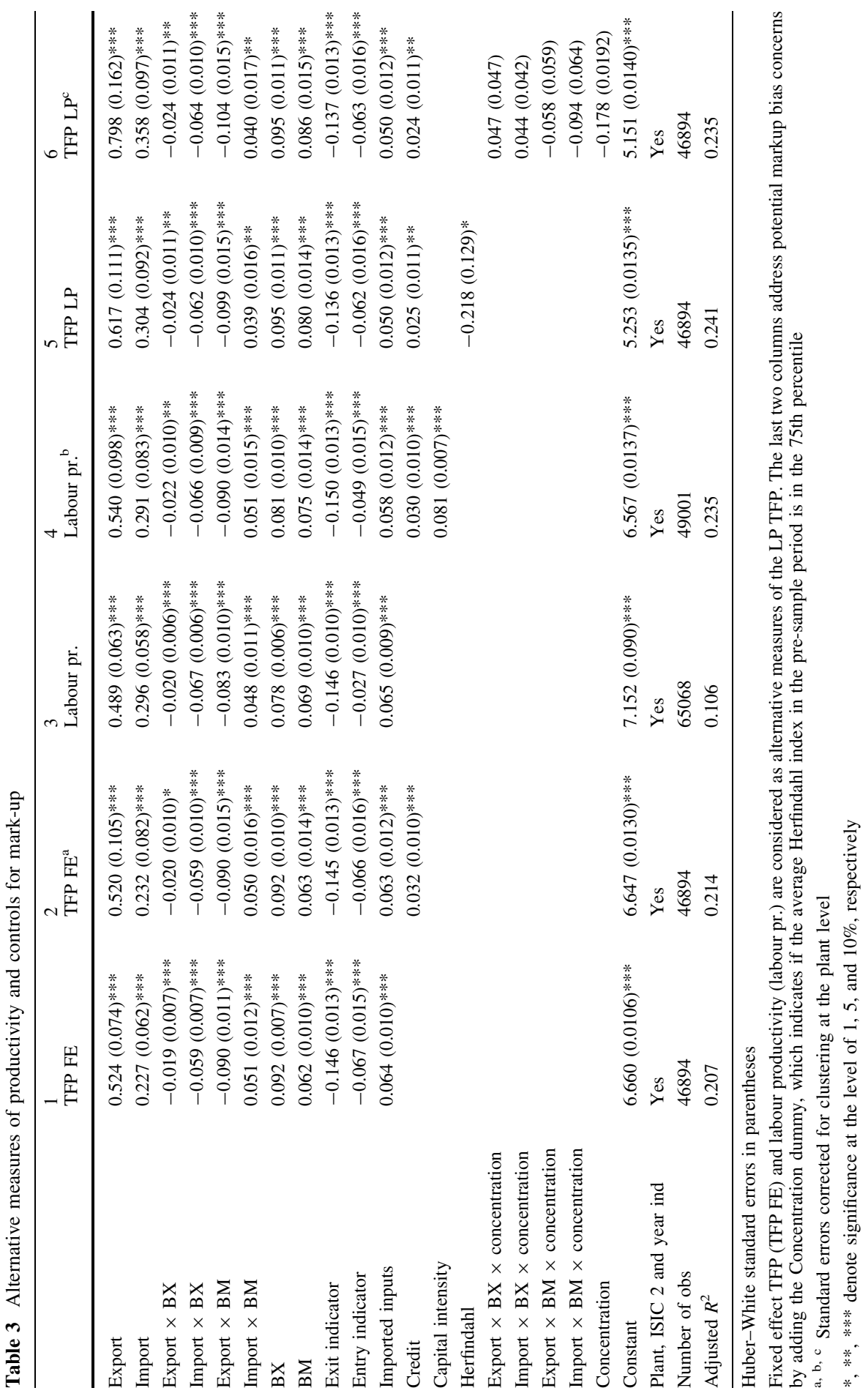


effects and TFP. Table 11 in Appendix 2 reports the results. The first column shows the regression using the TFP at 2-digit industry level and the second and third columns report the results considering the TFP based on production function estimates at the 3-digit. Our main results remain robust to all these alternative specifications. The coefficient of the interaction term between trade orientation and export border effects are negative, which suggests a positive link between export promotion and firm productivity. In the case of export oriented industries, however, the coefficient is only significant at $10 \%$ for the estimations using the TFP at 3-digit industry level (column 2). Concerning import border effects, results depend on the trade orientation of the industry. Confirming our previous finding, firm productivity in import competing industries is positively correlated with protection. On the other hand, the effect of import border effects on firms belonging to export oriented industries fails this time to show up at conventional levels of significance. For the sake of comparison, column 3 reports the regressions using the border effect estimated at 2-digit industry level and the TFP at 3-digit industry level. Here, results are quite closer to those obtained in the previous regressions of Table $2 .{ }^{18}$

Industry concentration and mark-ups As is common to the empirical literature on plant TFP estimations, this productivity measure is likely to be sensitive to markups variations. It is difficult to disentangle real (physical) productivity improvements from variations in value added arising from market power and price setting. In order to control for mark-up concerns, which are not captured by the individual fixed effects included in our previous regressions, we add the Herfindahl index of market concentration. This index is computed as the sum of the squared market shares in each 3-digit industry. Column 5 of Table 3 shows these results. Once we introduce the Herfindahl index the magnitude of the coefficients of the interaction terms between trade barriers and trade orientation remain entirely unchanged (see column 6 of Table 2). Market concentration is negatively correlated with plant productivity in these regressions.

If productivity improvements due to trade barrier reductions reflect variations in market power, this effect should be more important for firms producing in concentrated industries. Similar to previous works (Amiti and Konings 2007) we compute an additional robustness check introducing an interaction term between an industry concentration indicator, trade barriers and trade orientation indicators (Export $\times \mathrm{BX} \times$ concentration, Import $\times \mathrm{BX} \times$ concentration, Export $\times \mathrm{BM} \times$ concentration, Import $\times \mathrm{BM} \times$ concentration). The industry concentration dummy indicator is equal to one if the average of the Herfindahl index in the pre-sample period (1979-1981) is higher than 0.22 , which corresponds to the 75 th percentile. $^{19}$ The interaction terms of this concentration indicator with trade barriers and trade orientation indicators are not significant (column 6 of Table 3). This suggests that

\footnotetext{
${ }^{18}$ It should be stressed that our preferred measures of border effects are those used in the previous regressions (at 2-digit). The reason is that (1) the disaggregation of the analysis and (2) the inclusion of an enormous quantity of flows with little link to the Chilean economy leads to less plausible gravity estimates. Moreover, the use of a pseudo maximum likelihood methods relies on a certain type of heteroskedasticity that not necessarily matches the one implied in relative flows.

19 We use the pre-sample period due to the difference-in-difference framework and also in order to avoid endogenous changes in the Herfindahl index.
} 
there is no significant difference in productivity gains between low and high concentrated industries. Moreover, the coefficients of our key interaction terms between trade barriers and trade orientation indicators are not altered by the introduction of these controls.

Dynamic specification In this section, we perform a dynamic specification of Eq. 8 in which plant productivity depends on its past values. This implies the following auto-regressive multivariate model:

$$
\widehat{a}_{p t}=\theta_{0}+\theta_{1} \widehat{a}_{p t-1}+\zeta B_{s t}+\gamma T_{s}+\delta B_{s t} \cdot T_{s^{\prime}}+\varphi Z_{p t}+\xi_{p t}
$$

If we believe that the error term contains a specific time-invariant unobserved heterogeneity $\left(\xi_{p t}=v_{p}+\mu_{p t}\right)$, the lagged value of TFP, $\widehat{a}_{p t-1}$, is then endogenous to the error term (as it also contains $v_{p}$ ). Econometric literature provides well-known strategies for this dynamic issue. These strategies exploit moment conditions of exogeneity of the lags of the endogenous dependent variable. Here we use the GMM estimator of Arellano and Bond (1991). We include OLS and within-group (WG) estimators to identify an interval within which a consistent estimate of the autoregressive coefficient $\theta_{1}$ should lie (Bond 2002). The first column of Table 4 reports the OLS results, the second one the within-group estimates and finally, column 3 shows the GMM results. As expected, the coefficient of the autoregressive term (tfp_lp $(t-1))$ is higher when using OLS than in the case of withingroup regressions. This is a signal of a consistent dynamic specification, which means that the number of TFP lags on the right-hand side is correct. The set of instruments used in GMM estimation is composed of deep lags of border effect measures and TFP. Both set of variables are treated as endogenous. This provides an additional robustness check on the potential endogeneity issue between border effects and productivity mentioned in the step 2. The Hansen and Sargan tests validate our instrument choice. The number of individuals relative to the number of instruments is reassuring as regards any possible bias in the test when using a large number of instruments (Windmeijer 2005). We focus on GMM and within-group results. Dynamic regressions confirm the existence of plant productivity improvements after a reduction of export barriers in both traded industries. The positive sign in the interaction between import barriers and the import-competing indicator (Import $\times \mathrm{BM}$ ), also resists the dynamic control in GMM regressions. In the case of a within-group estimates this effect fails to be significant, though the autoregressive coefficient seems clearly downward biased.

On the contrary, the positive impact of import barrier reductions on plant productivity in export-oriented industries depends on the method. Within-group estimations confirm this finding (column 2), while in GMM regressions (column 3) the coefficient of the interaction between import barriers and the export-oriented indicator (Export $\times$ BM) becomes positive and significant. If GMM addresses the dynamic panel bias as it is expected, this result means that, once we control for the persistence of plant productivity series, foreign competition might also dampen domestic sales and plant productivity in export-oriented industries. Their high productivity trend overwhelms this effect in a static specification or in the case of a panel data bias in the within-group estimation. 
Table 4 Dynamic specification

\begin{tabular}{|c|c|c|c|}
\hline & 1 & $2^{\mathrm{a}}$ & $3^{\mathrm{b}}$ \\
\hline $\operatorname{TFP}(t-1)$ & $0.822(0.005)^{* * *}$ & $0.482(0.009)^{* * * *}$ & $0.741(0.091)^{* * *}$ \\
\hline Export & $0.233(0.044)^{* * *}$ & $0.400(0.101)^{* * *}$ & $-1.853(2.221)$ \\
\hline Import & $0.021(0.037)$ & $0.137(0.081)^{*}$ & $-1.061(1.731)$ \\
\hline Export $\times \mathrm{BX}$ & $-0.016(0.006)^{* * *}$ & $-0.020(0.008)^{* *}$ & $-0.233(0.067)^{* * *}$ \\
\hline Import $\times \mathrm{BX}$ & $-0.016(0.005)^{* * *}$ & $-0.034(0.008)^{* * *}$ & $-0.343(0.110)^{* * *}$ \\
\hline Export $\times \mathrm{BM}$ & $-0.030(0.008)^{* * *}$ & $-0.052(0.012)^{* * *}$ & $0.358(0.098)^{* * *}$ \\
\hline Import $\times \mathrm{BM}$ & $0.015(0.008)^{*}$ & $0.019(0.013)$ & $0.515(0.154)^{* * *}$ \\
\hline $\mathrm{BX}$ & $0.043(0.006)^{* * *}$ & $0.066(0.008)^{* * *}$ & $0.220(0.086)^{* *}$ \\
\hline $\mathrm{BM}$ & $-0.009(0.008)$ & $0.030(0.011)^{* * *}$ & $-0.346(0.113)^{* * *}$ \\
\hline Herfindahl & $-0.008(0.065)$ & $0.099(0.109)$ & $0.593(0.811)$ \\
\hline Exit indicator & $-0.148(0.012)^{* * *}$ & $-0.115(0.014)^{* * *}$ & $-0.262(0.039)^{* * *}$ \\
\hline Entry indicator & $0.000(0.000)$ & $0.000(0.000)$ & \\
\hline Credit & $0.041(0.006)^{* * *}$ & $0.013(0.009)$ & $0.604(0.266)^{* *}$ \\
\hline Imported inputs & $0.081(0.006)^{* * *}$ & $0.035(0.010)^{* * * *}$ & $0.077(0.137)$ \\
\hline Constant & $0.722(0.049)^{* * *}$ & $2.672(0.134)^{* * *}$ & \\
\hline Plant, ISIC 2 and year ind & Yes & Yes & Yes \\
\hline Number of obs & 35117 & 35117 & 31853 \\
\hline Adjusted $R^{2}$ & 0.757 & 0.287 & \\
\hline Sargan $\mathrm{p}$ & & & 0.160 \\
\hline Hansen $\mathrm{p}$ & & & 0.248 \\
\hline $\operatorname{AR}(2) p$ & & & $0.002^{\mathrm{c}}$ \\
\hline $\operatorname{AR}(3) p$ & & & 0.810 \\
\hline Instruments & & & 85 \\
\hline Individuals & & 5392 & 4911 \\
\hline
\end{tabular}

Huber-White standard errors in parentheses

a Standard errors corrected for clustering at the plant level

b The set of instruments is composed of lagged values of border effect and plant TFP. Both are treated as endogenous variables. As usual, we use industry and year indicators as exogenous instruments. Orthogonal transformations are used to maximize sample size

c Since the Arellano-Bond test of autocorrelation reveals that the disturbance might be in itself autocorrelated of order-1, but not further, we take lags between $t-4$ and $t-6$

$*$, **, *** denote significance at the level of 1,5 , and $10 \%$, respectively

\subsubsection{Trade liberalization channels}

Increasing returns to scale One of the novel findings in previous regressions is the negative impact of import barrier reductions on productivity gains of firms producing in import-competing industries. This result is robust to alternative measures of productivity and to controls of market power. In this subsection we provide additional evidence on the mechanism by which import competition might affect plant productivity. 
Table 5 Foreign competition and increasing returns to scale

\begin{tabular}{lllll}
\hline & 1 & 2 & 3 & $4^{\mathrm{a}}$ \\
\hline Increasing & $-0.505(0.211)^{* *}$ & $-0.953(0.216)^{* * *}$ & $-0.949(0.216)^{* * *}$ & $-0.949(0.243)^{* * *}$ \\
$\mathrm{BX}$ & $0.060(0.006)^{* * *}$ & $0.083(0.007)^{* * *}$ & $0.083(0.007)^{* * *}$ & $0.083(0.011)^{* * *}$ \\
$\mathrm{BM}$ & $0.040(0.008)^{* * *}$ & $-0.005(0.009)$ & $-0.006(0.009)$ & $-0.006(0.011)$ \\
Exit indicator & $-0.140(0.013)^{* * *}$ & $-0.136(0.013)^{* * *}$ & $-0.136(0.013)^{* * *}$ & $-0.136(0.013)^{* * *}$ \\
Entry indicator & $-0.061(0.016)^{* * *}$ & $-0.062(0.016)^{* * *}$ & $-0.062(0.016)^{* * *}$ & $-0.062(0.016)^{* * *}$ \\
Imported inputs & $0.047(0.010)^{* * *}$ & $0.049(0.010)^{* * *}$ & $0.049(0.010)^{* * *}$ & $0.049(0.012)^{* * *}$ \\
Credit & $0.028(0.009)^{* * *}$ & $0.025(0.009)^{* * *}$ & $0.025(0.009)^{* * *}$ & $0.025(0.011)^{* *}$ \\
Increasing $\times \mathrm{BM}$ & & $0.125(0.010)^{* * *}$ & $0.124(0.010)^{* * *}$ & $0.124(0.013)^{* * *}$ \\
Increasing $\times \mathrm{BX}$ & & $-0.030(0.006)^{* * *}$ & $-0.030(0.006)^{* * *}$ & $-0.030(0.009)^{* * *}$ \\
Herfindahl & & & $-0.226(0.097)^{* *}$ & $-0.226(0.125)^{*}$ \\
Constant & & $6.387(0.151)^{* * * *}$ & $6.401(0.151)^{* * *}$ & $6.401(0.173)^{* * *}$ \\
Plant, ISIC 2 and year ind & Yes & Yes & Yes & Yes \\
Number of obs & 46894 & 46894 & 46894 & 46894 \\
Adjusted $R^{2}$ & 0.232 & 0.233 & 0.232 & 0.232 \\
\hline
\end{tabular}

Huber-White standard errors in parentheses

${ }^{a}$ Standard errors corrected for clustering at the plant level

$*, * *, * * *$ denote significance at the level of 1,5 , and $10 \%$, respectively

As previously mentioned, the production function estimates in the first step reveal IRS in industries classified as import-competing. Hence, one possible explanation is that foreign competition reduces market shares of all firms and hampers the possibility to exploit economies of scale in import-competing industries. To illustrate this argument we provide regressions interacting trade barriers and a dummy indicating whether the plant operates in an industry under IRS (Increasing). ${ }^{20}$

Table 5 presents these results. Firms producing in industries operating under IRS have a lower productivity level than other firms (column 1). The interaction term between import barriers and the indicator of increasing returns to scale is positive and significant (column 2). This means that firms producing in industries under IRS suffer from foreign competition. As expected, the interaction term between export barriers and the indicator of increasing returns to scale is negative and significant. The reduction of export barriers increases market potential and enlarges the possibility to dynamically exploit scale economies (column 2). These results remain robust when we control for market concentration (column 3) and standard errors corrected for clustering at the plant level (column 4).

The better access to foreign technology In a developing country like Chile, the access to new technologies embodied in high-quality imported inputs and capital equipment may have a major role on productivity enhancements. This channel is present in our data. First, in previous regressions we found that firms producing with imported inputs have a higher TFP than those that only use domestic inputs. Second,

\footnotetext{
${ }^{20}$ The production function estimates show that industries operating under Increasing returns are Textile (32), Paper (34), Chemicals (35) and Machinery (38).
} 
Table 6 Import barriers on machinery and productivity (TFP LP)

\begin{tabular}{|c|c|c|c|c|c|c|}
\hline & 1 & 2 & 3 & 4 & 5 & $6^{\mathrm{a}}$ \\
\hline Export & $\begin{array}{l}0.950 \\
\quad(0.075)^{* * *}\end{array}$ & $\begin{array}{l}0.950 \\
\quad(0.075)^{* * * *}\end{array}$ & $\begin{array}{l}0.929 \\
\quad(0.075)^{* * *}\end{array}$ & $\begin{array}{l}0.928 \\
\quad(0.075)^{* * *}\end{array}$ & $\begin{array}{l}0.925 \\
\quad(0.075)^{* * *}\end{array}$ & $\begin{array}{l}0.925 \\
\quad(0.108)^{* * * *}\end{array}$ \\
\hline Import & $\begin{array}{l}0.482 \\
\quad(0.069)^{* * * *}\end{array}$ & $\begin{array}{l}0.491 \\
\quad(0.069)^{* * * *}\end{array}$ & $\begin{array}{l}0.504 \\
\quad(0.069)^{* * * *}\end{array}$ & $\begin{array}{l}0.502 \\
\quad(0.069)^{* * * *}\end{array}$ & $\begin{array}{l}0.505 \\
\quad(0.069)^{* * * *}\end{array}$ & $\begin{array}{l}0.505 \\
\quad(0.095) * * * *\end{array}$ \\
\hline Export $\times$ BK_M & $\begin{array}{l}-0.264 \\
\quad(0.013)^{* * *}\end{array}$ & $\begin{array}{l}-0.263 \\
\quad(0.013)^{* * * *}\end{array}$ & $\begin{array}{l}-0.259 \\
\quad(0.013)^{* * *}\end{array}$ & $\begin{array}{l}-0.259 \\
\quad(0.013)^{* * *}\end{array}$ & $\begin{array}{l}-0.259 \\
\quad(0.013)^{* * *}\end{array}$ & $\begin{array}{l}-0.259 \\
\quad(0.020) * * *\end{array}$ \\
\hline Import $\times$ BK_M & $\begin{array}{l}-0.105 \\
\quad(0.014)^{* * *}\end{array}$ & $\begin{array}{l}-0.107 \\
\quad(0.014)^{* * *}\end{array}$ & $\begin{array}{l}-0.105 \\
\quad(0.014)^{* * *} *\end{array}$ & $\begin{array}{l}-0.104 \\
\quad(0.014) * * *\end{array}$ & $\begin{array}{l}-0.104 \\
\quad(0.014)^{* * *}\end{array}$ & $\begin{array}{l}-0.104 \\
\quad(0.020)^{* * *}\end{array}$ \\
\hline BK_M & $\begin{array}{l}-0.103 \\
\quad(0.017)^{* * *}\end{array}$ & $\begin{array}{l}-0.143 \\
\quad(0.017)^{* * *}\end{array}$ & $\begin{array}{l}-0.147 \\
\quad(0.017)^{* * *}\end{array}$ & $\begin{array}{l}-0.149 \\
\quad(0.017)^{* * * *}\end{array}$ & $\begin{array}{l}-0.149 \\
\quad(0.017)^{* * *}\end{array}$ & $\begin{array}{l}-0.149 \\
\quad(0.022)^{* * *}\end{array}$ \\
\hline Exit indicator & & $\begin{array}{l}-0.141 \\
\quad(0.013)^{* * * *}\end{array}$ & $\begin{array}{l}-0.140 \\
\quad(0.013)^{* * *}\end{array}$ & $\begin{array}{l}-0.139 \\
\quad(0.013)^{* * * *}\end{array}$ & $\begin{array}{l}-0.138 \\
\quad(0.013)^{* * *}\end{array}$ & $\begin{array}{l}-0.138 \\
\quad(0.013)^{* * * *}\end{array}$ \\
\hline Entry indicator & & $\begin{array}{l}-0.059 \\
\quad(0.016)^{* * *}\end{array}$ & $\begin{array}{l}-0.059 \\
\quad(0.016)^{* * *}\end{array}$ & $\begin{array}{l}-0.060 \\
\quad(0.016)^{* * *}\end{array}$ & $\begin{array}{l}-0.059 \\
\quad(0.016)^{* * *}\end{array}$ & $\begin{array}{l}-0.059 \\
\quad(0.016)^{* * *}\end{array}$ \\
\hline Herfindahl & & & $\begin{array}{l}-0.250 \\
\quad(0.100)^{* *}\end{array}$ & $\begin{array}{l}-0.251 \\
\quad(0.100)^{* *}\end{array}$ & $\begin{array}{l}-0.252 \\
\quad(0.100)^{* * *}\end{array}$ & $\begin{array}{l}-0.252 \\
\quad(0.127)^{* *}\end{array}$ \\
\hline Imported inputs & & & & $\begin{array}{l}0.05 \\
\quad(0.010)^{* * *}\end{array}$ & $\begin{array}{l}0.050 \\
\quad(0.010)^{* * *}\end{array}$ & $\begin{array}{l}0.050 \\
\quad(0.012)^{* * *} *\end{array}$ \\
\hline Credit & & & & & $\begin{array}{l}0.024 \\
\quad(0.009)^{* * * *}\end{array}$ & $\begin{array}{l}0.024 \\
\quad(0.011)^{* *}\end{array}$ \\
\hline Constant & $\begin{array}{l}6.593 \\
\quad(0.114)^{* * * *}\end{array}$ & $\begin{array}{l}6.740 \\
\quad(0.114)^{* * * *}\end{array}$ & $\begin{array}{l}6.749 \\
\quad(0.114)^{* * *}\end{array}$ & $\begin{array}{l}6.729 \\
\quad(0.113)^{* * * *}\end{array}$ & $\begin{array}{l}6.720 \\
\quad(0.113)^{* * * *}\end{array}$ & $\begin{array}{l}6.720 \\
\quad(0.137)^{* * * *}\end{array}$ \\
\hline $\begin{array}{l}\text { Plant, ISIC } 2 \text { and } \\
\text { year ind }\end{array}$ & Yes & Yes & Yes & Yes & Yes & Yes \\
\hline Number of obs & 46894 & 46894 & 46894 & 46894 & 46894 & 46894 \\
\hline Adjusted $R^{2}$ & 0.116 & 0.120 & 0.120 & 0.121 & 0.121 & 0.121 \\
\hline
\end{tabular}

Huber-White standard errors in parentheses

a Standard errors corrected for clustering at the plant level

$*, * *, * * *$ denote significance at the level of 1,5 , and $10 \%$, respectively

in this subsection instead of using the import border effect at the 2-digit industry level for each industry, we only use the one corresponding to Machinery (BK_M) as a proxy of import barriers on capital equipment. The interaction term of this specific import border effect with the trade orientation dummies captures the extent to which plant productivity reacts to a better access to foreign capital goods. Table 6 reports the results of these regressions. Relative to non-traded industries, firms belonging to traded industries enhance their productivity after a reduction of import barriers on machinery industry. Moreover, productivity gains are significantly higher for plants in export-oriented industries (Export $\times$ BK_M) than in import-competing ones (Import $\times$ BK_M).

Foreign competition from low-wage countries The impact of foreign competition on plant productivity might be different depending on the characteristics of the exporting country. Responses of firms to changes in competition may differ across industries depending on exposure to competition from low-wage countries relative 
to high-wage countries. Using import penetration ratios, Bernard et al. (2006) find that US plant survival and employment growth are negatively associated to foreign competition from low-wage countries. ${ }^{21}$

In this subsection, we construct proxies of foreign competition from low-wage and high-wage countries by computing the weighted average of import border effect estimates for Latin American and Asian countries (low-wage countries), on the one hand, and for the US and EU (high-wage countries), on the other hand. Then we regress plant TFP on import border effect of low-wage countries (BM_lw) and on import border effect of high-wage countries (BM_hw). Table 12 in Appendix 2 shows the results. The impact of foreign competition on plant TFP depends on the origin of country. Plant TFP is negatively associated with foreign competition from low-wage country imports (column 1 and 2). However, we find plant TFP improvements after exposure to high-wage countries (column 1 and 2). In order to study whether these results are driven by the increasing returns to scale channel, we introduce an interaction term between the import border effect of low-wage (highwage) countries and the indicator of IRS (column 3). We find that the interaction term between import border effect of high-wage countries and the indicator of IRS is negative and significant, whereas the interaction term with import barriers from low-wage countries is positive and significant. Since Chile is a middle-income developing country, Chileans plants might benefit from positive technological spillovers from high-wage countries, while foreign competition from low-wage countries might affect negatively plant TFP due to the increasing returns to scale channel previously analyzed.

Distance to the frontier As claimed by Aghion et al. (2009) the response of firms' performance to changes in competition may differ across industries depending on distance to the technology frontier. In this subsection we test this channel by analyzing the impact of import barriers on plant TFP in interaction with the proximity to the technology frontier. The latter is measured as the ratio of the productivity of each plant relative to that of the most productive firm in the industry. ${ }^{22}$ Table 13 in Appendix 2 presents the results. We include several specifications: (a) border effects and proximity to the frontier at 2-digit in column 1; (b) the same model with an AR(1) of TFP in column 2; (c) the regressors (border effects and proximity) in lags in columns 3 and 4 in order to avoid, at least partially, reversal causality caveats, and (d) the proximity to the frontier and border effects at 3 -digit in columns 5 and 6 under contemporaneous and lagged specifications, respectively. The bottom part of the table shows the marginal effect of foreign competition (measured by the import border effects) at different values of the closeness to the frontier. It starts at the minimum (i.e., maximal distance) and increases gradually towards the maximum value (i.e., when firms are at the frontier).

While a differentiated effect appears it is more controversial than the one claimed by Aghion et al. (2009). In most of regressions what appears is indeed a positive effect of protection at the leading edge, excepting columns 5 and 6 in which the negative effect of protection is only significant for the very maximum level of

\footnotetext{
21 Thanks to an anonymous referee for pointing out this possible channel.

22 We thank an anonymous referee for pointing out this possible channel.
} 
productivity (i.e., when only the most productive firm is concerned). Whether this is a consequence of the fact that Chile might be itself far from the world technology frontier or a finding that casts doubt on the commonly accepted distance-to-frontier argument it is a matter of further research. In any case, it is worth noting that the empirical literature does not provide clear-cut results on the effect of competition on economic performance. ${ }^{23}$

\section{Conclusion}

The main contribution of this paper is to construct specific measures of trade barriers at the industry level in order to disentangle the impact of the reduction of export and import barriers on plant productivity. This distinction introduces new results. First, the reduction of export barriers improves productivity of plants belonging to both traded industries. As the export costs fall, more firms are able to export, increasing their size and probably benefiting from knowledge spillovers stemming from international markets. This encouraging result is robust to all robustness checks and specifications. Second, in all static specifications the reduction of import barriers shows a positive impact on the evolution of plant productivity in export-oriented industries relative to non-traded. However, this is not the case for plants belonging to import-competing industries producing with increasing returns to scale. The reduction of import barriers may prevent local firms to exploit economies of scale since they must share the local market with foreign competitors. Moreover, exporters' productivity also appears to have a negative reaction to foreign competition when a dynamic setting is considered.

Acknowledgments We are grateful to Pol Antras, Jose Miguel Benavente, Gene Grossman, Thierry Mayer, Jacques Mairesse, Nina Pavcnik, Andrea Repetto and James Tybout for helpful comments.

\section{Appendix 1}

\section{Classification of industries}

Export oriented industries: 311, 312, 331, 341, 372.

Import competing industries: 321, 322, 351, 354, 355, 361, 362, 381, 382, 383, $384,385,390$.

Non-traded industries: 313, 323, 324, 332, 342, 352, 353, 356, 369, 371.

\section{Appendix 2}

See Tables 7, 8, 9, 10, 11, 12, 13 and 14.

\footnotetext{
23 Just to give some examples see Crépon et Duguet (1997); Thingval and Podhal (2007); Blundell et al. (1999); Nicoletti and Scarpeta (2003)
} 
Table 7 Variables description

\begin{tabular}{|c|c|c|}
\hline & Variable & Data \\
\hline Export border effect & $\mathrm{BX}$ & $\begin{array}{l}\text { Export barriers at 2-digit industry level estimated by a gravity model } \\
\text { in step } 2\end{array}$ \\
\hline Import border effect & $\mathrm{BM}$ & $\begin{array}{l}\text { Import barriers at 2-digit industry level estimated by a gravity model } \\
\text { in step } 2\end{array}$ \\
\hline Export oriented sector & Export & $\begin{array}{l}\text { Dummy variable equal to one if the firm belongs to a } 3 \text { digit industry } \\
\text { with more than } 15 \% \text { of exports over output }\end{array}$ \\
\hline $\begin{array}{l}\text { Import competing } \\
\text { sector }\end{array}$ & Import & $\begin{array}{l}\text { Dummy variable equal to one if the firm belongs to a 3-digit industry } \\
\text { with more than } 15 \% \text { of import over output }\end{array}$ \\
\hline Market concentration & Herfindahl & Herfindahl index of market concentration at 3-digit industry level \\
\hline $\begin{array}{l}\text { Pre-sample } \\
\text { concentration }\end{array}$ & Concentration & $\begin{array}{l}\text { Dummy variable equal if the average Herfindahl index in the pre- } \\
\text { sample } \\
\text { period is in the } 75 \text { th percentile }\end{array}$ \\
\hline Imported inputs & $\begin{array}{l}\text { Imported } \\
\text { inputs }\end{array}$ & $\begin{array}{l}\text { Dummy variable equal to one if the plant reports having used imported } \\
\text { inputs }\end{array}$ \\
\hline Credit indicator & Credit & $\begin{array}{l}\text { Dummy variable equal to one if the plant reports having paid a loan } \\
\text { tax in year t }\end{array}$ \\
\hline
\end{tabular}

Table 8 Summary statistics by industry (2-digit ISIC Rev-2)

\begin{tabular}{lcllll}
\hline & Labour pr. & $\Delta$ Labour pr. & S/L & K/L & Exports share \\
\hline Food (31) & $5108(10204)$ & $0.10(0.66)$ & $0.13(0.11)$ & $3420(10709)$ & $0.09(0.2)$ \\
Textile (32) & $3828(3770)$ & $0.07(0.5)$ & $0.13(0.10)$ & $2198(8676)$ & $0.02(0.09)$ \\
Wood (33) & $4099(6428)$ & $0.11(0.93)$ & $0.11(0.10)$ & $2192(4143)$ & $0.07(0.18)$ \\
Paper (34) & $7119(9492)$ & $0.02(0.42)$ & $0.17(0.15)$ & $4775(14877)$ & $0.03(0.12)$ \\
Chemicals (35) & $10832(23366)$ & $0.07(0.57)$ & $0.16(0.11)$ & $4793(10573)$ & $0.04(0.13)$ \\
Non metallic (36) & $8130(14480)$ & $0.09(0.59)$ & $0.13(0.10)$ & $5356(16133)$ & $0.01(0.06)$ \\
Basic metals (37) & $34409(93787)$ & $0.13(0.71)$ & $0.19(0.14)$ & $7826(12033)$ & $0.18(0.31)$ \\
Machinery (38) & $5375(5987)$ & $0.10(0.68)$ & $0.16(0.13)$ & $3122(6519)$ & $0.02(0.07)$ \\
\hline
\end{tabular}

Mean of variables reported; standard deviation in parentheses

Labour pr.: labour productivity, $\Delta$ Labour pr.: Labour productivity growth, S/L: skill intensity, $\mathrm{K} / \mathrm{L}$ : capital intensity

Table 9 Correlation border effects at 3-digit and 2-digit industry level

\begin{tabular}{lll}
\hline & 1 & 2 \\
\hline BM 2dig & BM 3digit & BX 3digit \\
BX 2dig & $0.574(0.138)^{* * * *}$ & \\
constant & & $0.195(0.074)^{* * *}$ \\
Isic 2 dig FE & $-1.743(0.659)^{* * * *}$ & $-0.184(0.418)$ \\
Number of obs & Yes & Yes \\
Adjusted $R^{2}$ & 421 & 421 \\
\hline
\end{tabular}

$*$, **, *** denote significance at the level of 1,5 , and $10 \%$, respectively 
Table 10 TFP estimates at 3-digit industry level

\begin{tabular}{lrrrrrl}
\hline Industry & TFP LP & SD & TFP FE & SD & TFP OLS & SD \\
\hline Food & 7.61 & 1.03 & 8.23 & 1.09 & 5.67 & 0.88 \\
Food & 5.25 & 0.93 & 6.22 & 0.97 & 5.66 & 0.92 \\
Beverage & 6.30 & 0.95 & 9.25 & 1.15 & 6.58 & 0.92 \\
Textiles & 6.04 & 0.72 & 8.12 & 0.79 & 6.39 & 0.72 \\
Wearing apparel & 6.52 & 0.73 & 6.91 & 0.73 & 6.63 & 0.72 \\
Leather & 7.19 & 0.76 & 6.77 & 0.75 & 5.98 & 0.73 \\
Footwear & 6.56 & 0.67 & 7.46 & 0.72 & 6.37 & 0.66 \\
Wood & 6.99 & 0.85 & 7.39 & 0.85 & 6.30 & 0.81 \\
Furniture & 3.75 & 0.82 & 7.15 & 0.81 & 5.61 & 0.75 \\
Paper & 5.92 & 0.80 & 6.84 & 0.84 & 5.74 & 0.79 \\
Printing & 6.10 & 0.64 & 8.14 & 0.76 & 6.68 & 0.63 \\
Chemical & 9.62 & 1.13 & 10.76 & 1.26 & 6.77 & 0.99 \\
Other chemicals & 6.03 & 0.74 & 8.99 & 0.85 & 6.61 & 0.74 \\
Petroleum & 4.87 & 1.15 & 4.03 & 1.07 & 5.86 & 0.99 \\
Miscellaneous prod of petroleum & 9.65 & 1.32 & 12.79 & 1.72 & 7.18 & 1.22 \\
Rubber & 5.72 & 0.64 & 6.60 & 0.63 & 5.98 & 0.62 \\
Plastic & 6.19 & 0.77 & 7.13 & 0.75 & 6.90 & 0.75 \\
Pottery & 4.82 & 0.75 & 9.68 & 1.05 & 5.50 & 0.72 \\
Glass & 10.59 & 1.24 & 6.21 & 0.79 & 5.67 & 0.79 \\
Non-metallic & 6.92 & 0.94 & 7.53 & 0.97 & 6.38 & 0.90 \\
Iron and steel & 5.72 & 0.90 & 8.01 & 1.06 & 6.26 & 0.91 \\
Basic metal & 10.30 & 1.99 & 11.61 & 2.13 & 5.98 & 1.57 \\
Metal products & 6.33 & 0.72 & 7.67 & 0.75 & 6.56 & 0.72 \\
Machinery & 7.80 & 0.88 & 7.95 & 0.90 & 6.65 & 0.83 \\
Machinery apparatus & 5.55 & 0.82 & 7.19 & 0.84 & 6.22 & 0.80 \\
Transport equipement & 10.06 & 0.67 & 9.42 & 0.63 & 7.39 & 0.56 \\
\hline & & & & & &
\end{tabular}

Table 11 The impact of trade barriers on plant TFP (LP) measured at 3-digit

\begin{tabular}{llll}
\hline & 1 & 2 & 3 \\
& TFP 2dig & TFP 3dig & TFP 3dig \\
\hline Export & $-0.003(0.109)$ & $-0.007(0.112)$ & \\
Import & $0.039(0.098)$ & $0.049(0.096)$ & \\
Export $\times$ BX_3dig & $-0.024(0.018)$ & $-0.033(0.018)^{*}$ & \\
Import $\times$ BX_3dig & $-0.043(0.008)^{* * *}$ & $-0.040(0.008)^{* * *}$ & \\
Export $\times$ BM_3dig & $0.018(0.025)$ & $0.031(0.025)$ & \\
Import $\times$ BM_3dig & $0.025(0.008)^{* * *}$ & $0.023(0.007)^{* * *}$ & \\
BX_3dig & $0.009(0.005)^{* *}$ & $0.009(0.005)^{*}$ & \\
BM_3dig & $-0.010(0.005)^{* *}$ & $-0.010(0.005)^{* *}$ & $-0.860(0.360)^{* *}$ \\
Export & & & \\
\hline
\end{tabular}


Table 11 continued

\begin{tabular}{llll}
\hline & 1 & 2 & 3 \\
& TFP 2dig & TFP 3dig & TFP 3dig \\
\hline Import & & & $3.643(0.350)^{* * * *}$ \\
Export $\times$ BX_2dig & & & $-0.031(0.011)^{* * *}$ \\
Import $\times$ BX_2dig & & & $-0.069(0.010)^{* * *}$ \\
Export $\times$ BM_2dig & & & $-0.100(0.016)^{* * *}$ \\
Import $\times$ BM_2dig & & & $0.045(0.017)^{* * *}$ \\
BX_2dig & & $-0.153(0.019)^{* * *}$ & $0.097(0.011)^{* * *}$ \\
BM_2dig & & $-0.042(0.016)^{* *}$ & $-0.133(0.014)^{* * *}$ \\
Exit indicator & $-0.156(0.019)^{* * *}$ & $-0.061(0.016)^{* * *}$ \\
Entry indicator & $-0.041(0.017)^{* *}$ & $0.054(0.014)^{* * *}$ & $0.051(0.013)^{* * *}$ \\
Imported inputs & $0.056(0.014)^{* * *}$ & $0.009(0.012)$ & $0.022(0.011)^{* * *}$ \\
Credit & $0.010(0.012)$ & $0.025(0.015)^{* *}$ & $0.001(0.012)$ \\
Herfindahl & $0.038(0.015)^{* *}$ & $9.089(0.341)^{* * *}$ & $4.915(0.282)^{* * *}$ \\
constant & $6.252(0.235)^{* * * *}$ & Yes & Yes \\
Plant and year ind & Yes & Yes & Yes \\
ISIC 3 digit & Yes & No & Yes \\
ISIC 2 digit & No & 34391 & 44951 \\
Number of obs & 34391 & 0.528 & 0.567 \\
Adjusted $R^{2}$ & 0.224 & & \\
\hline
\end{tabular}

Huber-White standard errors in parentheses

Standard errors corrected for clustering at the plant level

$*, * *, * * *$ denote significance at the level of 1,5 , and $10 \%$, respectively

Table 12 Foreign competition from low-wage and high-wage countries

\begin{tabular}{llll}
\hline & 1 & 2 & 3 \\
& TFP 2dig & TFP 3dig & TFP 3dig \\
\hline BM_lw & $0.029(0.006)^{* * *}$ & $0.029(0.006)^{* * *}$ & $0.007(0.008)$ \\
BM_hw & $-0.033(0.006)^{* * *}$ & $-0.033(0.006)^{* * *}$ & $-0.012(0.008)$ \\
Exit indicator & $-0.153(0.019)^{* * *}$ & $-0.153(0.019)^{* * *}$ & $-0.153(0.019)^{* * *}$ \\
Entry indicator & $-0.041(0.016)^{* *}$ & $-0.041(0.016)^{* * *}$ & $-0.041(0.016)^{* *}$ \\
Imported inputs & $0.053(0.014)^{* * *}$ & $0.053(0.014)^{* * *}$ & $0.054(0.014)^{* * *}$ \\
Credit & $0.008(0.012)$ & $0.008(0.012)$ & $0.011(0.012)$ \\
Herfindahl & $0.030(0.015)^{* *}$ & $0.030(0.015)^{* *}$ & $0.041(0.015)^{* * *}$ \\
Increasing & & $-3.587(0.514)^{* * *}$ & $-3.635(0.508)^{* * *}$ \\
Increasing $\times$ BM_lw & & & $0.053(0.011)^{* * *}$ \\
Increasing $\times$ BM_hw & & & $-0.050(0.011)^{* * *}$ \\
Constant & $9.030(0.326)^{* * *}$ & $9.830(0.236)^{* * *}$ & $9.859(0.236) * * *$ \\
Plant and year ind & Yes & Yes & Yes \\
ISIC 3 digit & Yes & Yes & Yes \\
\hline
\end{tabular}


Table 12 continued

\begin{tabular}{llll}
\hline & 1 & 2 & 3 \\
& TFP 2dig & TFP 3dig & TFP 3dig \\
\hline Number of obs & 34367 & 34367 & 34367 \\
Adjusted $R^{2}$ & 0.522 & 0.521 & 0.521 \\
\hline
\end{tabular}

Huber-White standard errors in parentheses

Standard errors corrected for clustering at the plant level

$*$, **, *** denote significance at the level of 1,5 , and $10 \%$, respectively

Table 13 Distance to the frontier

\begin{tabular}{|c|c|c|c|c|c|c|}
\hline & (1) & (2) & (3) & (4) & (5) & (6) \\
\hline Proximity 2 dig & $\begin{array}{l}0.217 \\
\quad(0.017)^{* * * *}\end{array}$ & $\begin{array}{l}0.194 \\
\quad(0.022)^{* * * *}\end{array}$ & & & & \\
\hline BM_2dig & $\begin{array}{l}-0.128 \\
\quad(0.007)^{* * * *}\end{array}$ & $\begin{array}{l}-0.117 \\
\quad(0.009)^{* * * *}\end{array}$ & & & & \\
\hline $\begin{array}{l}\text { proximity } 2 \text { dig } \times \\
\text { BM_2dig }\end{array}$ & $\begin{array}{l}0.064 \\
\quad(0.003)^{* * * *}\end{array}$ & $\begin{array}{l}0.053 \\
\quad(0.003)^{* * * *}\end{array}$ & & & & \\
\hline Exit indicator & $\begin{array}{l}-0.049 \\
\quad(0.008)^{* * * *}\end{array}$ & $\begin{array}{l}-0.050 \\
\quad(0.009)^{* * * *}\end{array}$ & $\begin{array}{l}-0.117 \\
\quad(0.014)^{* * * *}\end{array}$ & $\begin{array}{l}-0.131 \\
\quad(0.014) * * *\end{array}$ & $\begin{array}{l}-0.047 \\
\quad(0.007)^{* * *} *\end{array}$ & $\begin{array}{l}-0.132 \\
\quad(0.015)^{* * * *}\end{array}$ \\
\hline Entry indicator & $\begin{array}{r}-0.005 \\
(0.009)\end{array}$ & $\begin{array}{l}0.000 \\
\quad(0.000)\end{array}$ & $\begin{array}{l}0.000 \\
\quad(0.000)\end{array}$ & $\begin{array}{l}0.000 \\
\quad(0.000)\end{array}$ & $\begin{array}{r}-0.010 \\
(0.009)\end{array}$ & $\begin{array}{l}0.000 \\
\quad(0.000)\end{array}$ \\
\hline Imported inputs & $\begin{array}{l}0.015 \\
\quad(0.007)^{* *}\end{array}$ & $\begin{array}{l}0.010 \\
\quad(0.007)\end{array}$ & $\begin{array}{l}0.028 \\
\quad(0.010)^{* * * *}\end{array}$ & $\begin{array}{l}0.050 \\
\quad(0.011)^{* * * *}\end{array}$ & $\begin{array}{l}0.021 \\
\quad(0.007)^{* * *}\end{array}$ & $\begin{array}{l}0.031 \\
\quad(0.011)^{* * * *}\end{array}$ \\
\hline Credit & $\begin{array}{l}0.011 \\
\quad(0.006)^{*}\end{array}$ & $\begin{array}{l}0.004 \\
\quad(0.006)\end{array}$ & $\begin{array}{l}0.014 \\
\quad(0.009)\end{array}$ & $\begin{array}{l}0.014 \\
\quad(0.010)\end{array}$ & $\begin{array}{l}0.007 \\
\quad(0.006)\end{array}$ & $\begin{array}{l}0.016 \\
\quad(0.010)\end{array}$ \\
\hline Herfindahl & $\begin{array}{l}0.050 \\
\quad(0.007)^{* * * *}\end{array}$ & $\begin{array}{l}0.038 \\
\quad(0.008)^{* * * *}\end{array}$ & $\begin{array}{l}0.020 \\
\quad(0.010)^{* * *}\end{array}$ & $\begin{array}{r}-0.012 \\
(0.011)\end{array}$ & $\begin{array}{l}0.158 \\
\quad(0.008)^{* * * *}\end{array}$ & $\begin{array}{l}0.014 \\
\quad(0.012)\end{array}$ \\
\hline $\operatorname{TFP}(t-1)$ & & $\begin{array}{l}0.238 \\
\quad(0.006)^{* * * *}\end{array}$ & $\begin{array}{l}0.492 \\
\quad(0.011)^{* * * *}\end{array}$ & & & \\
\hline $\begin{array}{l}\text { Proximity } 2 \mathrm{dig} \\
\quad(t-1)\end{array}$ & & & $\begin{array}{l}0.010 \\
\quad(0.011)\end{array}$ & $\begin{array}{l}0.199 \\
\quad(0.012)^{* * * *}\end{array}$ & & \\
\hline BM_2dig $(t-1)$ & & & $\begin{array}{l}0.030 \\
\quad(0.007)^{* * * *}\end{array}$ & $\begin{array}{l}0.032 \\
\quad(0.008)^{* * * *}\end{array}$ & & \\
\hline $\begin{array}{l}\text { Proximity 2dig } \times \\
\text { BM_2dig }(t-1)\end{array}$ & & & $\begin{array}{c}-0.003 \\
(0.002)\end{array}$ & $\begin{array}{l}0.008 \\
\quad(0.002)^{* * * *}\end{array}$ & & \\
\hline Proximity 3 dig & & & & & $\begin{array}{l}0.608 \\
\quad(0.005)^{* * * *}\end{array}$ & \\
\hline BM_3dig & & & & & $\begin{array}{l}0.017 \\
\quad(0.003)^{* * * *}\end{array}$ & \\
\hline $\begin{array}{l}\text { Proximity } 3 \text { dig } \times \\
\text { BM_3dig }\end{array}$ & & & & & $\begin{array}{l}-0.005 \\
\quad(0.001)^{* * *}\end{array}$ & \\
\hline $\begin{array}{l}\text { Proximity } 3 \mathrm{dig} \\
\quad(t-1)\end{array}$ & & & & & & $\begin{array}{l}0.243 \\
\quad(0.006)^{* * * *}\end{array}$ \\
\hline BM_3dig $(t-1)$ & & & & & & $\begin{array}{l}0.013 \\
\quad(0.004)^{* * * *}\end{array}$ \\
\hline
\end{tabular}


Table 13 continued

\begin{tabular}{|c|c|c|c|c|c|c|}
\hline & (1) & (2) & (3) & (4) & (5) & (6) \\
\hline $\begin{array}{r}\text { Proximity } 3 \operatorname{dig} \times \\
\text { BM_3dig }(t-1)\end{array}$ & & & & & & $\begin{array}{l}-0.005 \\
\quad(0.001)^{* * * *}\end{array}$ \\
\hline Constant & $\begin{array}{l}7.522 \\
\quad(0.133)^{* * * *}\end{array}$ & $\begin{array}{l}3.764 \\
\quad(0.197)^{* * * *}\end{array}$ & $\begin{array}{l}2.142 \\
\quad(0.285)^{* * * *}\end{array}$ & $\begin{array}{l}4.642 \\
\quad(0.275)^{* * * *}\end{array}$ & $\begin{array}{l}3.698 \\
\quad(0.212)^{* * * *}\end{array}$ & $\begin{array}{l}4.244 \\
\quad(0.303)^{* * * *}\end{array}$ \\
\hline $\begin{array}{l}\text { Year and sector } \\
\text { dummies }\end{array}$ & Yes & Yes & Yes & Yes & Yes & Yes \\
\hline Number of obs & 44951 & 33668 & 33668 & 33668 & 43928 & 31273 \\
\hline Adjusted $R^{2}$ & 0.800 & 0.757 & 0.555 & 0.295 & 0.878 & 0.666 \\
\hline \multicolumn{7}{|c|}{ Marginal effects of Import barriers } \\
\hline Minimum & $\begin{array}{l}-0.680 \\
\quad(0.029) * * *\end{array}$ & $\begin{array}{l}-0.572 \\
\quad(0.037)^{* * * *}\end{array}$ & $\begin{array}{l}0.040 \\
\quad(0.012)^{* * * *}\end{array}$ & $\begin{array}{l}0.003 \\
\quad(0.013)\end{array}$ & $\begin{array}{l}0.063 \\
\quad(0.010)^{* * * *}\end{array}$ & $\begin{array}{l}0.031 \\
\quad(0.009)^{* * * *}\end{array}$ \\
\hline Mean less $1 \mathrm{SD}$ & $\begin{array}{l}-0.085 \\
\quad(0.006)^{* * *}\end{array}$ & $\begin{array}{l}-0.080 \\
\quad(0.007)^{* * * *}\end{array}$ & $\begin{array}{l}0.027 \\
\quad(0.007)^{* * * *}\end{array}$ & $\begin{array}{l}0.038 \\
\quad(0.006)^{* * * *}\end{array}$ & $\begin{array}{l}0.016 \\
\quad(0.002)^{* * * *}\end{array}$ & $\begin{array}{l}0.011 \\
\quad(0.003) * * *\end{array}$ \\
\hline Mean & $\begin{array}{l}-0.012 \\
\quad(0.005)^{* * * *}\end{array}$ & $\begin{array}{l}-0.021 \\
\quad(0.005)^{* * * *}\end{array}$ & $\begin{array}{l}0.024 \\
\quad(0.006)^{* * *} *\end{array}$ & $\begin{array}{l}0.047 \\
\quad(0.006)^{* * *}\end{array}$ & $\begin{array}{l}0.007 \\
\quad(0.001)^{* * * *}\end{array}$ & $\begin{array}{l}0.004 \\
\quad(0.002)^{* *}\end{array}$ \\
\hline Mean plus $1 \mathrm{SD}$ & $\begin{array}{l}0.061 \\
\quad(0.005)^{* * * *}\end{array}$ & $\begin{array}{l}0.038 \\
\quad(0.006)^{* * * *}\end{array}$ & $\begin{array}{l}0.021 \\
\quad(0.006)^{* * * *}\end{array}$ & $\begin{array}{l}0.055 \\
\quad(0.007)^{* * * *}\end{array}$ & $\begin{array}{r}-0.002 \\
(0.001)\end{array}$ & $\begin{array}{r}-0.003 \\
(0.002)\end{array}$ \\
\hline Maximum & $\begin{array}{l}0.168 \\
\quad(0.008)^{* * *}\end{array}$ & $\begin{array}{l}0.127 \\
\quad(0.009)^{* * * *}\end{array}$ & $\begin{array}{l}0.017 \\
\quad(0.007)^{* * *}\end{array}$ & $\begin{array}{l}0.068 \\
\quad(0.008)^{* * *}\end{array}$ & $\begin{array}{l}-0.026 \\
\quad(0.005)^{* * *}\end{array}$ & $\begin{array}{l}-0.021 \\
\quad(0.007) * * *\end{array}$ \\
\hline
\end{tabular}

Huber-White standard errors in parentheses

Standard errors corrected for clustering at the plant level

$*$, **, *** denote significance at the level of 1,5 , and $10 \%$, respectively

Table 14 Trade policy instruments

Year Trade policies

1975 National Agency for Export Promotion: to promote Chilean's exports by improving the international insertion of Chilean's firms

1976 Elimination of all non-tariffs barriers

1979 Uniform import tariff of $10 \%$

1980 Economic complementation agreements: Latin American Integration Association (ALADI)

Export Promotion Programme: to supply information on foreign markets and customers, promoting Chilean exports through generic publicity and targeted missions, and working to resolve the administrative problems faced by exporters

1983 Increase import tariff to $20 \%$

1984 Increase import tariff to $35 \%$

1985 Reduction of import tariffs to $20 \%$

Economic Positioning Campaign: to diffuse the country image in external markets. The programme is financed and organized jointly by PROCHILE and other organizations

1988 Reduction of import tariffs to $15 \%$

1991 Reduction of import tariffs to $11 \%$ 
Table 14 continued

Year Trade policies

1992 Bilateral FTA (ECA No. 17) with Mexico: 2 programes of linear tariff reduction lasting 4 and 6 years. Establishement of NTB

Rules of Origin: Based on modified LAIA and NAFTA

Commercial Information System (CIS): PROCHILE provides information to firms about international markets (prices, transport costs, entrance regulation and trade barriers.)

1993 Bilateral FTA with Venezuela (ECA No. 23): Tariff elimination programme to be completed by 1999

1993 Bilateral FTA with Bolivia (ECA No. 22): Tariff elimination programme to be completed by 1999

1994 Bilateral FTA with Colombia (ECA No. 24): Tariff elimination programme

1995 Bilateral FTA with Ecuador (ECA No. 32): Tariff elimination programme to be completed by 2000

1996 FTAwith MERCOSUR (ECA No. 35): Tariffelimination programme under way; completed by January 2014

Participation in institutional structure of MERCOSUR

1997 Bilateral FTA with Cananda. Tariff elimination programmes under way as scheduled; process will be completed in 2014. Opening of negotiations on financial services. Scheduled for 1999

1998 Bilateral FTA with Peru (ECA No. 32): Tariffelimination programme under way; to be completed by 1 January 2012

2002 Bilateral FTA with the US

2003 EU grants immediate tariff-free access for $85 \%$ of Chilean exports to the EU and provides for annual reductions in import tariffs on the remainder, culminating in zero tariffs for 96 percent of exports by 2007 and 100 percent tariff-free access by 2013

2004 Bilateral FTA with Korea

Source ECLAC

\section{References}

Aghion, P., Blundell, R., Griffith, R., Howitt, P. \& Prantl, S. (2009). The effects of entry on incumbent innovation and productivity. Review of Economics and Statistics, 91(1), 20-32.

Alvarez, R., \& Lopez, R. (2005). Exporting and performance: Evidence from Chilean plants. Canadian Journal of Economics, 38(4), 1384-1400.

Amiti, M., \& Konings, J. (2007). Trade liberalization, intermediate inputs, and productivity: Evidence from Indonesia. American Economic Review, 97(5), 1611-1638.

Anderson, J. E., \& van Wincoop, E. (2003). Gravity with gravitas : A solution to the border puzzle. American Economic Review, 93(1), 170-192.

Anderson, J. E., \& van Wincoop, E. (2004). Trade costs. Journal of Economic Literature, 42(1), 691-751.

Arellano, M., \& Bond, S. (1991). Some tests of specification for panel data: Monte Carlo evidence and an application to employment equations. Review of Economic Studies, 58(1), 277-297.

Baier, S. L., \& Bergstrand, J. H. (2001). The growth of world trade: Tariffs, transport costs and income similarity. Journal of International Economics, 53(1), 1-27.

Bond, S. (2002). Dynamic panel data models: A guide to micro data methods and practice. Portuguese Economic Journal, 1, 141-162.

Bergoeing, R., Kehoe, P. J., Kehoe, T. J., \& Soto, R. (2002). Policy-driven productivity in Chile and Mexico in the 1980s and 1990s. American Economic Association, 92(2), 16-21.

Bergoeing, R., Loayza, N. \& Repetto, A. (2004). Slow recoveries. Journal of Development Economics, 75(2), 473-506.

Bergoeing, R., Micco, A. \& Repetto, A. (2005). Dissecting the Chilean export boom. (Working Paper CEA), Universidad de Chile. 
Bergoeing, R., Hernando, A., \& Repetto, A. (2006). Market reforms and efficiency gains in Chile. (Working Paper CEA), University of Chile.

Bernard, A. B., Jensen, J. B., \& Shott, P. K. (2006). Survival of the best fit: Exposure to low-wage countries and the (uneven) growth of US manufacturing plants. Journal of International Economics, 68(1), 219-237.

Blundell, R., Griffith, R. \& Van Reenen, J. (1999). Market share, market value and innovation in a panel of British manufacturing firms. Review of Economic Studies, 66(3), 529-554.

Crépon, B. \& Duguet, E. (1997). Research and development, competition and innovation pseudo maximum likelihood and simulated maximum likelihood methods applied to count data models with heterogeneity. Journal of Econometrics, 79, 355-378.

De Loecker, J. (2007). Do exports generate higher productivity? Evidence from Slovenia. Journal of International Economics, 73(1), 69-98.

Devarajan, S. \& Rodrik, D. (1989). Trade liberalization in developing countries: Do imperfect competition and scale economies matter? The American Economic Review, 79(2), 283-287.

Feenstra, R. C. (2003). Advanced international trade: Theory and evidence. Princeton: Princeton University Press.

Fontagné, L., Mayer, T. \& Zignago, S. (2005). Trade in the triad: How easy is the access to large markets? Canadian Journal of Economics, 38(4), 1402-1430.

Harrigan, J. (1996). Openness to trade in manufactures in the OECD. Journal of International Economics, 40(1-2), 23-39.

Head, K., \& Mayer, T. (2000). Non-Europe: The magnitude and causes of market fragmentation in Europe. Weltwirschaftliches Archiv/Review of World Economics, 136(2), 285-314.

Greene, W. (2008). Econometric analysis. Englewood Cliffs: Prentice Hall editions.

Kasahara, H., \& Rodriguez, J. (2008). Does the use of imported intermediates increase productivity? Plant-level evidence. Journal of Development Economics, 87, 106-118.

Katayama, H., Lu, S. \& Tybout, J. (2009). Firm-level productivity studies: Illusions and a solution. International Journal of Industrial Organization, 27, 403-413.

Kraay, A. (2002). Exports and economic performance: Evidence from a panel of Chinese firms. In Renard M. F. (Ed.) China and its regions, economic growth and reform in Chinese Provinces (pp. 278-299). Cheltenham: Edward Elgar.

Levinsohn, J., \& Petrin, A. (2003). Estimating production functions using inputs to control for unobservables. Review of Economic Studies, 70(2), 317-341.

Liu, L., \& Tybout, J. (1996). Productivity growth in Colombia and Chile: Panel-based evidence on the role of entry, exit and learning. In Roberts, M. \& Tybout, J. (Eds.) Industrial Evolution in Developing Countries. New York : Oxford University Press.

McCallum, J. (1995). National borders matter. American Economic Review, 85(3), 615-623.

Nicita, A., \& M. Olarreaga (2001). Trade and production, 1976-99. (Policy research working paper series 2701). Washington, DC: World Bank.

Nicoletti, G., \& Scarpetta, S. (2003). Regulation, productivity and growth: OECD evidence. Economic Policy, 36, 9-72.

Olley, S., \& Pakes, A. (1996). The dynamics of productivity in the telecommunication equipment industry. Econometrica, 64(6), 1263-1298.

Pavcnik, N. (2002). Trade liberalisation, exit and productivity improvement: Evidence from Chilean plants. Review of Economic Studies, 69(1), 245-276.

Redding, S., \& Venables, A. (2004). Economic geography and international inequality. Journal of International Economics, 62(1), 53-82.

Rodrik, D. (1992). Closing the technology gap: Does trade liberalization really help? In H. Gerald (Ed.) Trade policy, industrialization and development: New perspectives. Oxford: Clarendon Press.

Santos Silva, J. M. C. \& Tenreyro, S. (2006). The log of gravity. Review of Economics and Statistics, 88, 641-658.

Schor, A. (2004). Heterogeneous productivity response to tariff reduction: Evidence from Brazilian manufacturing firms. Journal of Development Economics, 75(2), 373-396.

Tingvall, P. \& Poldahl, A. (2006). Is there really an inverted U-shaped relation between competition and R\&D. Economics of Innovation and New Technology, 15(2), 101-118.

Windmeijer, F. (2005). A finite sample correction for the variance of linear eficient two-step GMM estimators. Journal of Econometrics, 126(1), 25-51. 